DIW BERLIN

Discussion

Papers
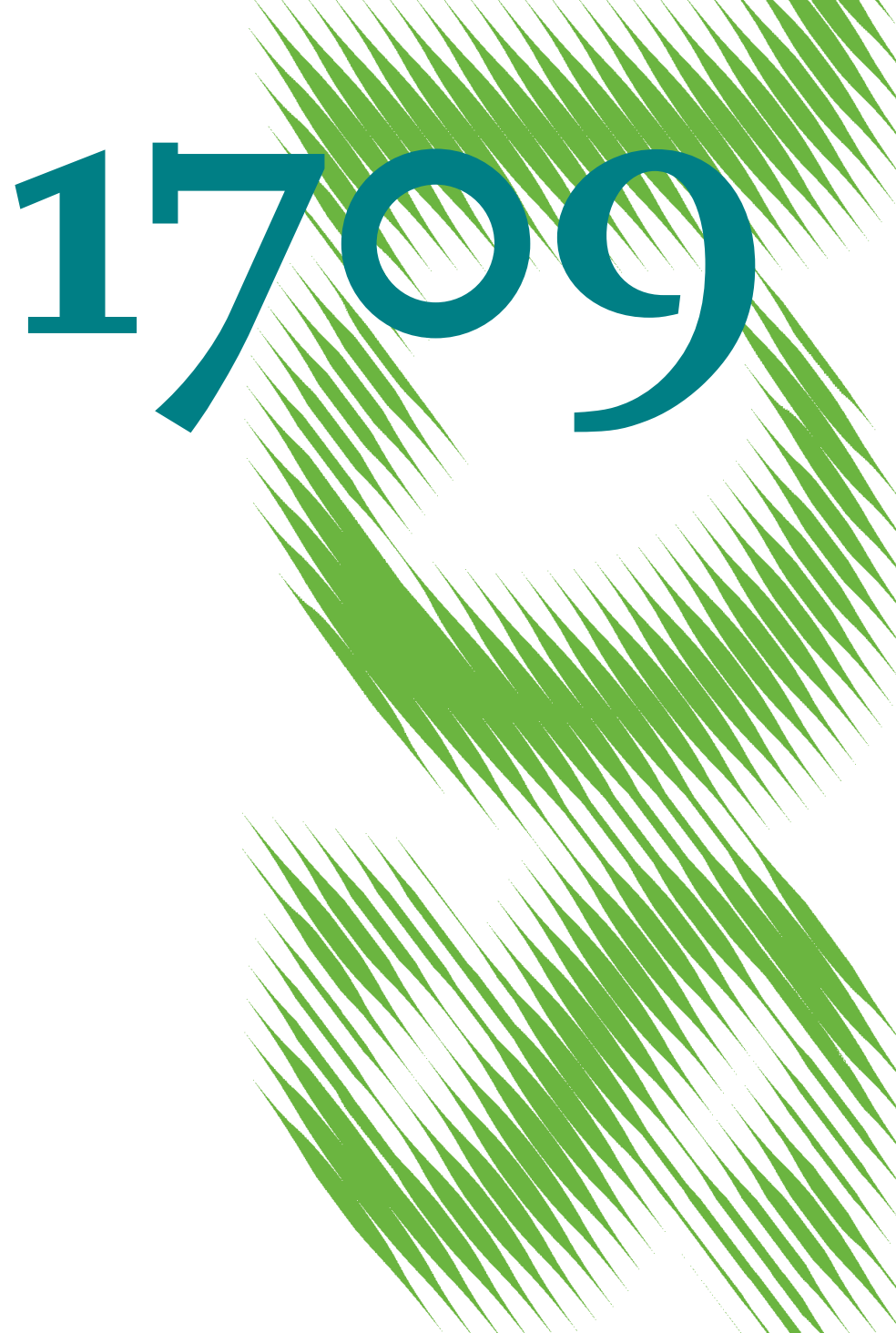

Intergenerational Effects of Education on Risky Health Behaviours and Long-Term Health 
Opinions expressed in this paper are those of the author(s) and do not necessarily reflect views of the institute.

IMPRESSUM

(C) DIW Berlin, 2017

DIW Berlin

German Institute for Economic Research

Mohrenstr. 58

10117 Berlin

Tel. +49 (30) $89789-0$

Fax +49 (30) $89789-200$

http://www.diw.de

ISSN electronic edition 1619-4535

Papers can be downloaded free of charge from the DIW Berlin website:

http://www.diw.de/discussionpapers

Discussion Papers of DIW Berlin are indexed in RePEc and SSRN:

http://ideas.repec.org/s/diw/diwwpp.html

http://www.ssrn.com/link/DIW-Berlin-German-Inst-Econ-Res.html 


\title{
Intergenerational effects of education on risky health behaviours and long-term health
}

\author{
Mathias Huebener* \\ DIW Berlin \& Freie Universität Berlin
}

December 2017

\begin{abstract}
This paper estimates the causal effects of parental education on their children's risky health behaviours and health status. I study the intergenerational effects of a compulsory schooling reform in Germany after World War II. Implemented across federal states at different points in time, the reform increased the minimum number of school years from eight to nine. Instrumental variable estimates and difference-in-differences estimates reveal that increases in maternal schooling reduce children's probability to smoke and to be overweight in adolescence. The effects persist into adulthood, reducing chronic conditions that often result from unhealthy lifestyles. No such effects can be identified for paternal education. Increased investments in children's education and improvements in their peer environment early in life are important for explaining the effects. Changes in family income, family stability, fertility and parental health-related behaviours are less relevant empirically. The intergenerational effects of education on health and health-related behaviours exceed the direct effects. Studies neglecting the intergenerational perspective substantially understate the full causal effects.
\end{abstract}

Keywords: Parental education, returns to education, smoking, overweight, compulsory schooling

JEL: I12, I20

*E-mail: mhuebener@diw.de. Acknowledgements: I am grateful for comments by Pedro Carneiro, Christian Dustmann, Daniel Kuehnle, Jan Marcus, Steve Pischke, C. Katharina Spiess and participants of the workshop IWAEE 2017 in Catanzaro and "Risky health behaviors" in Hamburg. I also thank Mandy Huebener and Adam Lederer for valuable comments. I acknowledge financial support by the German National Academic Foundation and the German Ministry of Education and Research (Project: "Nicht-monetäre Erträge von Bildung in den Bereichen Gesundheit, nicht-kognitive Fähigkeiten sowie gesellschaftliche und politische Partizipation", NIMOERT2/\#30857). 


\section{Introduction}

Smoking, high blood pressure, being overweight, physical inactivity, and high blood glucose are the leading health risk factors in high-income countries. The World Health Organization (WHO, 2009) estimates that these factors account for more than fifty percent of pre-mature deaths. They are related to unhealthy lifestyles that are highly correlated with individuals' level of education. Educational differences in health behaviours are undoubtedly an important reason for the strong educational gradient in health status, chronic conditions, and longevity (e.g. Cutler and Lleras-Muney, 2010; Cawley and Ruhm, 2011; Mazumder, 2012). ${ }^{1}$

The extent to which the link between education, health-related behaviours and health is causal is subject to ongoing debate. Studies using exogenous variation in education produce mixed findings and are far from being conclusive (Cawley and Ruhm, 2011; Lochner, 2011; Clark and Royer, 2013; Grossman, 2015). What is more, previous studies on causal effects almost exclusively focus on the immediate effects of education on health and health behaviours. However, education is also transmitted to children (Black, Devereux, and Salvanes, 2005; Oreopoulos, Page, and Stevens, 2006; Holmlund, Lindahl, and Plug, 2011; Piopiunik, 2014; Dickson, Gregg, and Robinson, 2016). As many healthrelated behaviours, such as smoking or dietary habits, may already be determined early in life before education reforms set in, we may miss a substantial share of the causal link between education, health-related behaviours and health if intergenerational effects are neglected.

This paper aims at closing the gap and estimates the intergenerational effects of education on health behaviours and long-term health. It studies the impact of parental schooling on children's smoking behaviour and being overweight, and traces the effects on chronic conditions and long-term health into children's adulthood. Both smoking and

\footnotetext{
${ }^{1}$ Differences in health behaviours do not fully explain the educational gradient in health. This issue is not the focus of this paper.
} 
being overweight are important causes of future health problems and chronic conditions (such as cardiovascular diseases, type 2 diabetes, and cancer) as well as premature death (e.g. Must, 1999). While smoking is itself a risky health behaviour, being overweight is closely related to other common risky health behaviours, such as physical inactivity or a poor diet (see, e.g., Hill, 1998, 2003; Janssen et al., 2005). Despite the large number of ways through which parental education may affect children's health behaviours and health status, there may still be other determinants that correlate with parental education and falsely propose a causal link to children's health-related outcomes, such as parents' genetic endowments, general health, or character traits. Identification of causal effects requires exogenous variation in parental education, which I draw from a compulsory schooling reform in Germany. The reform increased the minimum number of school years from eight to nine, stepwise across federal states between 1949 and 1969. The analysis builds on data from the German Micro Census, an annual representative survey of one percent of all households in Germany. I focus on children aged 15 to 18 living with their parents. I also use supplementary data from the German Socio-Economic Panel Study (SOEP), tracking the effects into children's adulthood after they moved out from home. Carrying out the analysis for Germany has an advantage for the identification of causal effects compared to, for example, the US: The German education system tracks students into different schools mainly based on their ability. The compulsory schooling reform only affected students in the basic track. As the reform did not impact the completed school track of affected parents, the additional school track variation enables me to also estimate difference-in-differences models with children of basic track parents. I can also perform placebo tests and estimate triple-differences models using children with parents from higher tracks. The results pass a large set of robustness checks.

The main findings of the paper are as follows: One additional year of maternal education reduces children's probability to smoke (3.8 percentage points, or about 17 percent) and to be overweight (4.5 percentage points, or about 26 percent) in adolescence. The effects persist into children's adulthood, eventually lowering the risk of chronic conditions and 
improving the general health status. For smoking, the effects mainly arise because children never initiate smoking. Although fathers' years of schooling also correlate highly with children's health-related outcomes, I find no evidence for causal effects of increases in paternal education.

The effects are best explained by increased investments in children's human capital and its dynamic formation throughout life (Cunha and Heckman, 2007; Heckman, 2007). I present evidence that children of treated mothers obtain higher levels of education, they attend better school tracks and are exposed to a better peer environment in school during adolescence - a critical period for the initiation of smoking and other risky behaviours (such as drinking and substance abuse). This may already be a result of improved human capital at birth and throughout childhood (e.g. Currie and Moretti, 2003; Chou, Liu, Grossman, and Joyce, 2010; Lindeboom, Llena-Nozal, and van der Klaauw, 2009) which can promote further human capital formation (e.g. Behrman and Rosenzweig, 2004; Black, Devereux, and Salvanes, 2007; Case, Fertig, and Paxson, 2005). These increased levels of education also improve children's earnings prospects, and probably their discount rates and risk aversion, which may all decrease the utility drawn from engaging in unhealthy behaviours (Fuchs, 1982; Becker and Mulligan, 1997; Cutler and Lleras-Muney, 2010). I test other theoretical channels through which increases in maternal schooling could improve children's health behaviours and health status, including changes in family income and mating (which allows living in better neighbourhoods, or to purchase sports club memberships, better health services, or better food, see, e.g., Currie and Stabile, 2003; Carneiro, Meghir, and Parey, 2013), family stability and fertility (which may change the time and material investments parents can invest in their children, see, e.g., Hanushek, 1992; Francesconi, Jenkins, and Siedler, 2010), and parental health behaviours (as parents may serve as a role model, see, e.g. Powell and Chaloupka, 2005). The empirical relevance of these channels appears small overall, although even small changes in these dimensions may accumulate and contribute to substantial improvements in unhealthy behaviours and long-term human capital. 
The study makes several important contributions: First, I extend the scarce literature on the long-term effects of educational interventions that focuses mainly on children's schooling outcomes (e.g. Black et al., 2005; Oreopoulos et al., 2006; Holmlund et al., 2011; Piopiunik, 2014; Dickson et al., 2016). I add novel evidence on intergenerational effects on health behaviours and health status that are likely moderated by increases in children's education. The fact that interventions can unfold substantial long-term effects is encouraging for programmes that initially have small direct effects on treated individuals, as in the "zero-returns to compulsory schooling" reform analysed in Pischke and von Wachter (2008), which is also the basis of this analysis. The long-term effects further justify public investments in education as individuals would typically not consider these spill-over effects in their educational investment decisions.

Second, I provide the first evidence for causal effects of parental schooling on children's health behaviours. The large literature on the causal effects of education on health behaviours exclusively focuses on the direct effects within the same generation (Lochner, 2011; Clark and Royer, 2013; Grossman, 2015). ${ }^{2}$ My intergenerational perspective contributes to the literature on the strong associations between socio-economic status (SES) and health status, chronic conditions and longevity, for which SES gaps in health behaviours are an important explanation (e.g. Baum and Ruhm, 2009; Cawley and Ruhm, 2011). The results suggest that the intergenerational SES transmission also operates through the impact of mothers' education on children's health behaviours, and eventually on their health.

Third, I go beyond child outcomes in adolescence and demonstrate effects of parental schooling on children's health behaviours and health status when they are themselves adults. The small literature on intergenerational effects of education on health mainly

\footnotetext{
${ }^{2}$ Some studies document correlations between parental education and children's health behaviour (Waldron and Lye, 1990; Lowry, Kann, and Collins, 1996) or try to estimate the causal effect using parental background information as instruments for parental schooling (e.g. Kemptner and Marcus, 2013). However, these instruments do not credibly overcome the endogeneity problem (Kenkel, Lillard, and Mathios, 2006).
} 
focuses on health outcomes around childbirth. It mostly points towards improvements in child health at birth, and a more health-oriented behaviour of mothers during pregnancy (e.g. Currie and Moretti, 2003; Chou et al., 2010; McCrary and Royer, 2011). Few studies examine the effects of parental schooling on health-related outcomes in later childhood and adolescence (Lindeboom et al., 2009; Carneiro et al., 2013; Lundborg, Nilsson, and Rooth, 2014). They do not consider health behaviours and find no robust evidence on children's overweight. ${ }^{3}$ I provide the first robust evidence for maternal schooling effects on children's smoking behaviour and being overweight as adolescents, and show that these effects persist into adulthood. I also show that children are less likely to suffer from chronic conditions and report better general health as adults.

Fourth, the study shows that education has substantial non-market benefits, even if the income channel is closed. This is an important contribution to the growing literature on non-market benefits of education, which typically cannot disentangle the effects of education from effects of higher incomes. Increased schooling typically increases earnings, and it has many further benefits for individuals and society, such as reducing the risk of welfare dependence, teenage fertility, and health problems, engaging less in crime (see, e.g., Oreopoulos and Salvanes, 2011, for an overview) - or improving health status and health-related behaviours of children, as I demonstrate. However, it used to be unclear whether effects of education on non-market outcomes are a result of higher incomes or of

\footnotetext{
${ }^{3}$ These studies consider being overweight or obese as an outcome variable among others, but data limitations or limitations in the identification strategy may cause some sizeable point estimates to be imprecisely estimated and insignificant. Lindeboom et al. (2009), exploiting the UK's 1947 increase in the minimum school leaving age, find little evidence for effects on several child health outcomes at ages 7 , 11 , and 16, including weight problems. Identification is based on a regression discontinuity (RD) design exploiting cohort variation in parents' minimum schooling requirements. This approach needs to rely on assumptions on general cohort trends, with RD-estimates likely underestimating the effects of the minimum schooling policy (Lochner, 2011). Carneiro et al. (2013) estimate effects of maternal education on a large number of child outcomes at ages 7-8 and 12-14. They instrument maternal schooling with regional and family characteristics that alter individuals' costs of schooling. The rather weak instrument results in imprecise estimates, such that some sizeable effects on being overweight (e.g. white children aged 7-8) only turn significant in robustness checks. Lundborg et al. (2014) study intergenerational effects of a set of education reforms on measures of cognitive and non-cognitive skills as well as a rich set of child health indicators, including obesity at age 18 in a sample of military draftees limited to males. IVestimates on obesity appear small, but given the low incidence of only two percent of obese individuals in the sample, the estimates suggest substantial obesity reductions of 33 to 50 percent, which are only imprecisely estimated.
} 
more schooling per se (Oreopoulos and Salvanes, 2011). A major challenge in the literature is to disentangle the two because the policy implications vary widely. My analysis builds on a reform for which Pischke and von Wachter (2008) report zero-returns to compulsory schooling. Consequently, this leads to a natural experiment in which the income channel is mostly closed. I also find no evidence for reform effects on household income. My findings complement Lundborg et al. (2014), for whom it appears that income effects can explain most of the effects of maternal schooling on children's cognitive skills and health. I suggest that a multiplicity of factors is at work.

The remainder of the paper is organised as follows. Section II provides information about the German education system and compulsory schooling law changes. Section III introduces the data and outlines the empirical strategy. I present the main results in Section IV and a large set of sensitivity checks in Section V. Section VI concludes.

\section{The compulsory schooling reform in West Germany}

At the time of the compulsory schooling reform, children typically entered primary school at age six and attended school jointly for four years. Thereafter, students were abilitytracked into three different secondary school tracks: The basic school track (Volksschule or Hauptschule) with school completion after eight or nine years of schooling, the middle track (Realschule) with completion after ten years of schooling, and the high-ability track (Gymnasium) with completion after 13 years of schooling. ${ }^{4}$ Students completing the high track earned the general university entrance qualification and could study at university. Students from the basic and middle tracks typically proceeded with vocational trainings. The basic track was attended by about eighty percent of students around 1940. As the availability of places at higher tracks has expanded rapidly since the 1950s, the share

\footnotetext{
${ }^{4}$ The mechanism for selecting students into the different school tracks varies across cohorts and federal states. Generally, it depends on grades in primary school, teacher recommendations, parental choice, or, for the high-ability track, formal admission exams. Mobility between tracks after initial assignment is generally very low (Dustmann, 2004).
} 
gradually declined to below fifty percent by $1970 .{ }^{5}$

After World War II, all West German federal states increased the minimum number of school years in the basic school track from eight to nine. The reform was implemented at different points in time across federal states (see Appendix Table B.1). It is exploited in other studies analysing the impact of increases in schooling on labour market outcomes (Pischke and von Wachter, 2008; Kamhöfer and Schmitz, 2016), health behaviours and health status of the affected generation (Kemptner, Jürges, and Reinhold, 2011), civic engagement (Siedler, 2010), and fertility (Cygan-Rehm and Maeder, 2013). Piopiunik (2014) uses the reform to study the effects on children's school track. The studies by Cygan-Rehm and Maeder (2013) and Piopiunik (2014) report slightly different years of the reform in four small states. I adhere to Pischke and von Wachter (2008), but the main findings reported in this paper are also robust to using the alternative reform dates. Cohorts affected by the reform had to stay in school one year longer. The first cohorts with a ninth grade in the basic track are born between 1934 (in Hamburg) and 1955 (in Bavaria).

The motives for introducing a ninth grade vary across states, probably because the goals of basic schooling shifted over time in post-war Germany. The first reforms in the early postwar period, such as in Hamburg, were motivated by high youth unemployment rates and limited vocational training places (Schneider, 1952). In the Hamburg Accord (Hamburger Abkommen) of 1964, all federal states agreed that the minimum number of school years should be nine, emphasising educational and developmental goals of an additional school year. The economy needed better-educated individuals, and transitioning 14-year old children into the labour market may be harmful for their development because they are in a vulnerable stage of their psychological development (Petzold, 1981). ${ }^{6}$

\footnotetext{
${ }^{5}$ In the empirical analysis, the general increase in education levels in the population is accounted for by cohort-fixed effects and state-specific time trends. A large set of robustness checks is dedicated to ruling out that the empirical model still captures some general trends not related to increases in compulsory schooling.

${ }^{6}$ In some states, the introduction of the ninth grade was preceded by local and temporary introductions of a ninth grade. For example, before the ninth grade became compulsory in the states of Bavaria (1969)
} 
In the additional grade, continued general education was a focus. Students would typically be continuously taught in the main subjects (e.g. mathematics, language arts, sciences, and vocational preparation). The exact curricula differed partly between states. For example, the federal state of Bremen focused on general knowledge, while Niedersachsen focused more on consolidating basic skills and on teaching political responsibility (Petzold, 1981; Pischke and von Wachter, 2008).

\section{Data and empirical strategy}

\section{A. Data}

The analysis is based on the German Micro Census, an annual representative survey of one percent of all households in Germany (RDC, 2017). Participation in the Micro Census is required by law. The scientific use file of the rich data contains a 70 percent random subsample. Although the data is used in studies on the causal effects of education on health behaviours and health status (see, e.g., Kemptner et al., 2011), and on intergenerational associations in education outcomes (see, e.g., Riphahn and Trübswetter, 2013), this is the first study using the data to estimate intergenerational effects of education.

The large data set contains rich socio-economic information, including the highest school degree, labour market outcomes, the state of residence, the birth year, and information on children in the household. I focus on children aged 15 to 18, as the share living with their parents is very high at 97.6 percent in 2009, and stable over time (96.8 percent in 1989, see Appendix Table B.2). Additionally, the age distribution of children aged 18 and below living with their parents is stable over time (see Appendix Figure A.1). This is because most children live with their parents until they complete vocational training or until they graduate from the academic track school and because they need parental

and Niedersachsen (1962), these states allowed counties and towns to mandate a temporary ninth grade in the early 1950s to reduce youth labour market tensions. The findings are robust to controlling for potentially affected cohorts of the temporary introduction of a ninth grade (see Section V). 
approval to move out before age $18 .^{7}$

I determine parents' years of schooling based on their highest school degree and the typical number of years required to obtain this degree. I assume that parents went to school in the state they currently live in. This assumption seems reasonable, as cross-state mobility is low in Germany: 85 percent of individuals aged 40 to 50 still live in the state they went to school in (based on data from the German Socio-Economic Panel Study, SOEP, see Wagner, Frick, and Schupp, 2007). I focus the analysis mainly on parents with basic track schooling, of which 91 percent still live in their schooling state. ${ }^{8}$

Health-related questions are asked in several waves of the Micro Census to a 45 percent random subsample of households. Information on smoking behaviour is available in the surveys from 1989, 1995, 1999, 2003, 2005, and 2009; information on self-reported body height and weight for the years 1999, 2003, 2005, and 2009. To make best use of the available information, I pool all waves constituting two random samples. ${ }^{9}$

I focus the analysis on two main outcomes: Smoking and being overweight. While smok-

\footnotetext{
${ }^{7}$ To rule out that my findings are confounded by changes in children's moving-out behaviour, I also restrict the sample to children aged 15-16, when they are almost exclusively still in school and living at home. Furthermore, I estimate the effects in data from the German Socio-Economic Panel Study (SOEP), in which information on children is also available after moving out from home. The Micro Census data contain direct pointers from children to mothers and fathers in the household from 2005 onward. In earlier waves, identifying parents is possible based on children's relationship to the household head, information on household heads' partners, their marital status, and an age-range plausibility check on the potential parents (especially in multi-generational households). Using data from the 2005 Micro Census including the parent-pointers for cross-validation, I can identify about 98 percent of parents correctly. Any differences between survey waves that may arise from the improvement in reporting quality after 2005 should be unrelated to the compulsory schooling reforms, and are accounted for by survey year fixed-effects. In the German Micro Census, information on smoking behaviour is only available from age 15 onward.

${ }^{8} \mathrm{I}$ look at parental place of residence in their $40 \mathrm{~s}$, because parents are about 30 years old when their child is born, and I observe their children at age 15-18. As in other international data, direct measures on years of schooling are rare in German data. Assigning the usual length of schooling based on the highest educational degree is a typical procedure in the literature (Stephens and Yang, 2014). For a subsample, I calculate the years of schooling based on the year of the final educational degree and find similar, though noisier first stage coefficients.

${ }^{9}$ The Micro Census follows a subsample of individuals for four consecutive waves, but the health related questions appear only once during this period. As health information only became available after 1989 and as I consider children up to age 18, I over-represent younger parental cohorts. The results are robust to weighting the regressions with inverse probability weights to represent the original distribution of birth cohorts in the population (see Section V.B).
} 
ing is an important risky health behaviour, the overweight measure serves as an indicator for individual's general health status that is also related to other common risky health behaviours, such as low levels of physical activity or a poor diet (see, e.g., Hill, 1998, 2003; Janssen et al., 2005). Both outcomes are strong predictors of future health problems and chronic conditions (such as heart diseases, diabetes and cancer), and they are key determinants of major health risks in high-income countries (WHO, 2009). In my analysis, the smoking variable takes the value one if adolescents smoke regularly or occasionally. The overweight assessment is based on adolescents' body mass index (BMI, calculated from body height and weight) and standard overweight thresholds for Germany (KromeyerHauschild et al., 2001). Children are classified as overweight if their BMI is above the age-dependent 90th percentile-threshold. This definition is employed in other analyses on child obesity in Germany (see, e.g., Cawley and Spiess, 2008; Reinhold and Jürges, 2012). I also use the international thresholds based on Cole et al. (2000) in a robustness check.

Responding to the health-related questions in the Micro Census is voluntary, and selfreporting is potentially prone to social desirability bias or misreporting. Unless potential misreporting or missing information are systematically related to parents' being affected by the compulsory schooling reform, the causal effect analysis is not biased. Whether misreporting is an issue cannot be tested directly. Still, I can compare the reported body height and the body weight information to a large representative health survey of children in Germany that is based on external assessments rather than self-reporting (KiGGS study, conducted between 2003 and 2006 by the Robert Koch-Institute, see Kurth, 2007). The average body height in the Micro Census is slightly larger, and the body weight slightly lower. ${ }^{10}$ With respect to missing information, I run a multivariate regression of missings in children's health-related information on their age, gender, parents' years

\footnotetext{
${ }^{10}$ For example, 15 -year old girls' average height (weight) was 165 centimetres (59.9 kilograms) in the KiGGS study, and 166 centimetres (57.4 kilograms) in the 2005 Micro Census. 15-year old boys' average height (weight) was 175.1 centimetres (66.4 kilograms) in the KiGGS study, and 174.4 centimetres (65.1 kilograms) in the 2005 Micro Census (these values are within the 95 percent confidence interval). For details, see Stolzenberg, Kahl, and Bergmann (2007). Smoking is also self-reported in other surveys and cannot be validated by external assessments.
} 
of schooling, and household income (Panel A of Appendix Table B.3). The probability for missing information in smoking behaviour decreases with age. Parental education correlates positively with missing information. I test for a causal relationship between missing information and parental schooling within the estimation framework outlined in Section III.B and cannot find evidence (Panel B of Table B.3). Therefore, missing information are also not biasing effect estimates.

In the empirical analysis, I focus on parents in West Germany (excluding Berlin) who were born between 1930 and 1960. Descriptive statistics on the main samples are reported in Appendix Table B.4.

\section{B. Empirical strategy}

I estimate the causal effects of mothers' and fathers' schooling $S_{i}^{p}$ on child $i$ 's health-related outcome $H_{i}$ separately with the following model:

$$
\begin{aligned}
\mathrm{H}_{i}= & \alpha_{1} \mathrm{~S}_{i}^{p}+\alpha_{2}(\text { birth year FE })^{p}+\alpha_{3}(\text { state FE })^{p} \\
& +\alpha_{4}(\text { state-time trend })^{p}+X_{i}^{\prime} \alpha_{5}+u_{i}
\end{aligned}
$$

To overcome potential endogeneity in parental years of schooling, I use the introduction of a ninth grade in the basic school track as an instrumental variable (IV) $Z_{i}^{p}$ for parental schooling $S_{i}^{p}$ :

$$
\begin{aligned}
\mathrm{S}_{i}^{p}= & \beta_{1} \mathrm{Z}_{i}^{p}+\beta_{2}(\text { birth year FE })^{p}+\beta_{3}(\text { state } \mathrm{FE})^{p} \\
& +\beta_{4}(\text { state-time trend })^{p}+X_{i}^{\prime} \beta_{5}+\epsilon_{i}
\end{aligned}
$$

The introduction of a ninth grade in the basic school track varied across cohorts and federal states. Conditional on parents' birth cohort ("birth year FE") and federal state ("state FE"), parental exposure to the compulsory schooling reform is exogenous. Stephens and Yang (2014) stress the importance of accounting for region-specific trends when using regional variation in compulsory schooling laws for identification, as differential, regionspecific improvements in, e.g., economic conditions may falsely be assigned to changes in compulsory schooling and overestimate the true benefits. To rule out that differences in 
regional trends are driving the estimated effects, I include interaction terms of parental state of residence dummies with a linear trend in their year of birth ("state-time trend"). The vector $X_{i}$ includes dummies for children's age, gender, and the survey year. The model accounts for policy changes at the federal level (such as cigarette tax increases) through birth year dummies, survey wave dummies and children's age dummies. Their combination controls flexibly for children's year of birth and parents' age. The IV-strategy is similar to previous studies using education reforms to estimate the intergenerational effects of education, such as Holmlund et al. (2011) and Chou et al. (2010).

The resulting IV-estimator is the Wald estimator that rescales the reduced form effects by the first stage effects. For the identification of causal effects of increases in compulsory schooling, the German tracking systems provides an advantage over other school systems without tracking, such as the US: The reform was only binding for students in the basic track. Other school tracks already had more years of schooling. For treated basic track students, the required number of years in school increases by one, and the first stage coefficient from eq. 2 within this subsample equals one.

This feature is useful for two reasons: First, if the compulsory schooling reform had no effect on the highest school degree parents obtain, I can estimate the reduced form for children with parents from the basic track. Children with parents from higher tracks constitute a natural placebo group to test whether the reform coefficients capture effects related to parents' compulsory schooling increase or general trends unaccounted for by the model. Second, estimating the reduced form model in the complier-sample, rather than the IV-model, can result in more precise estimates. I estimate the following difference-indifferences model in subgroups based on parents' school track:

$$
\begin{aligned}
\mathrm{H}_{i}= & \gamma_{1} \mathrm{Z}_{i}^{p}+\gamma_{2}(\text { birth year FE })^{p}+\gamma_{3}(\text { state FE })^{p} \\
& +\gamma_{4}(\text { state-time trend })^{p}+X_{i}^{\prime} \gamma_{5}+\xi_{i}
\end{aligned}
$$

The notation follows analogously, and the coefficient of main interest is $\gamma_{1}$. 
The identification strategy rests crucially on the common trend assumption. In the robustness section, I perform several checks (beyond the checks in the placebo sample) on the plausibility of this assumption. I check whether the results are sensitive to the inclusion of state-time trends or control variables, I perform a series of placebo-reforms assuming that the ninth grade was introduced earlier and I estimate the effects on a health-related, but mostly genetically determined, placebo outcome (adult body height, as it is less malleable than body weight). I then use parents from higher school tracks as an additional control group in a difference-in-differences-in-differences model to account for potential nonlinear state-specific trends. I also forgo the comparison to other states and estimate effects based on the idea of a regression discontinuity model in which state-trends in children's health behaviours are interrupted by the introduction of the ninth grade for some parents. Finally, I provide graphical evidence reassuring that unaccounted trends are not driving the results.

All models are estimated with robust standard errors clustered at the state by parental year of birth level. ${ }^{11}$

\section{Results}

\section{A. The compulsory schooling reform and mothers' schooling}

I first analyse the effect of the changes in compulsory schooling on mothers' educational attainment, the first stage for the IV-estimations. In Panel A of Table 1, I estimate the reform effect on mothers' years of schooling with the model from eq. 2. In both samples, with information on children's smoking behaviour and overweight, mothers' years of schooling increase by 0.48 and 0.65 years, respectively, with the introduction of a compulsory ninth grade in the basic school track. The effect is highly statistically significant with

\footnotetext{
${ }^{11}$ I draw the same conclusions if I cluster standard errors at the federal state level. In this case, I account for the small number of ten clusters with Wild Cluster Bootstrap procedures (for details, see Cameron, Gelbach, and Miller, 2008). Table B.5 reports the results.
} 
F-statistics above 20. The estimated effects on mothers' years of schooling differ between the samples (although not statistically) because children's overweight is observed in later waves of the German Micro Census than children's smoking behaviour. The data then contains fewer mothers born early in the observation period when the share of students in the basic track was higher. Due to educational expansions during this period, the share of women attending higher school tracks increased continuously. Such general, nationwide, trends in educational attainments are independent of the compulsory schooling reform and accounted for by the empirical model.

Increases in the years of schooling may result from the basic track requirement to stay in school for one more year, or from upgrades of students to higher school tracks that require more years of schooling. I estimate the reform effect on the probability of completing school with the basic track degree instead of a higher track degree (Panel B of Table 1). The point estimates are very small and insignificant, suggesting that the introduction of a ninth grade increases schooling only through increases in basic track schooling. Consequently, the reform effect on mothers' schooling reflects the mean share of mothers enrolled in the basic track when the reform was implemented in the federal states. ${ }^{12}$

\section{B. Parental schooling and children's health-related outcomes in adolescence}

I now turn to the question of whether parental schooling impacts children's health behaviours and health status. In Panel A of Table 2, I first estimate the relationship between children's smoking behaviour and being overweight at age 15 to 18, and mothers' years of schooling using ordinary least squares regressions, as outlined in eq. 1, and find a strong correlation.

\footnotetext{
${ }^{12}$ As I do not observe years of schooling directly in the data, I assign the typical number of school years for different school degrees based on parents' year of birth and the federal state they live in. From 2005 onward, the Micro Census contains information on the year in which individuals completed their latest professional degree. I use this information in the much smaller sample to estimate the effect of the compulsory schooling change on mothers' years of schooling (see Appendix Table B.6). The point estimates on the observed years of schooling are similar to estimates on the imputed number of years of education, but due to the much smaller sample size and measurement error in the reported information, it is less precisely estimated.
} 
To circumvent the potential endogeneity problem in mothers' educational attainment, I instrument mother's years of schooling using a dummy for the introduction of a ninth grade in the basic track. The IV-estimates suggest that one additional year of mothers' schooling significantly reduces the probability that children smoke (3.8 percentage points) and are overweight (4.5 percentage points). The IV-estimates are larger than the OLS estimates. One reason for this may be that more education has particularly large effects at low levels of parental education (e.g. Imbens and Angrist, 1994). ${ }^{13}$

We may be worried that the IV-estimates capture general trends in children's outcomes rather than the causal effects of changes in compulsory schooling. First note that the general trends in children's outcome variables go in opposite directions: While adolescence smoking is downward-trending after 2000, overweight is upward-trending. Cohort-specific trends are taken into account by a set of dummies for mothers' birth year, children's age and the survey year. Further, the empirical model allows for state-specific trends in mothers' birth year.

To test whether unaccounted trends may still drive the results, I make use of the German tracking system. I directly estimate the reduced form effects of changes in compulsory schooling in subsamples stratified by the maternal school track completed (Panel B of Table 2). In the sample with mothers from the basic track, where the compulsory schooling law was binding (and where the first stage equals one), the reduced form estimates are very similar to the IV-estimates, and more precisely estimated for overweight. Mothers from higher school tracks - born in the same birth years and residing in the same states - were not affected by the reform. I use children of these mothers as a placebo group and find that the estimated effects are small and insignificant. ${ }^{14}$ To get an idea of relative

\footnotetext{
${ }^{13}$ Alternatively, the estimates may be upward biased because of measurement error in mothers' years of schooling. Bingley and Martinello (2017) estimate a bias in returns to education of 38 percent in Danish data. The reason is that years of schooling is a bounded variable in which measurement error is non-classical, typically resulting in a negative correlation with the true value. Accounting for this potential source of bias leads to point estimates that are still larger than OLS estimates (smoking 2.4 percentage points, being overweight 2.8 percentage points), suggesting that the local average treatment effects of an additional year of maternal schooling are indeed substantial.

${ }^{14}$ I also calculate IV-weights based on the formulas provided in Løken, Mogstad, and Wiswall (2012)
} 
effect sizes, it is important to determine an appropriate baseline level. Relating the point estimates to the sample mean would be misleading, because of trending outcome variables and substantial differences in outcomes by parental education, i.e. between children from complying mothers from low tracks and always-taking mothers from higher school tracks. Therefore, I calculate the baseline level from counterfactual outcomes of children with mothers from the low track. Consequently, one more year of maternal education reduces children's smoking rates by about 17 percent, and the incidence of overweight by about 26 percent. $^{15}$

In Table 3, I investigate the effects on children's health behaviours and health status in more detail. I provide the IV-estimates (Panel A) followed by the reduced form effects for mothers from basic tracks (Panel B). To immediately check whether the common trend assumption is plausible for this set of outcomes, I report the estimates for children of unaffected mothers below. The reductions in smoking are mainly caused by children who never start smoking, but there are also small effects on quitting rates (only significant in reduced form, see columns 1-2). Moreover, increased maternal schooling reduces regular smoking, but there are also small reductions in occasional smoking (only significant in IV-estimates, see columns 3-4). Conditional on smoking, I find no effects on the age at smoking initiation or on the number of cigarettes smoked (columns 5-6).

With respect to children's weight problems, the effect on being overweight is similar if the BMI-thresholds determining overweight are based on international reference values reported in Cole et al. (2000), rather than the reference values for Germany as in Kromeyer-Hauschild et al. (2001, see column 7). However, the effect is less precisely estimated and just turns insignificant (the reduced form estimate has a p-value of 0.115).

to identify the part of the maternal education distribution that is contributing to the linear IV-estimates. The IV-estimators assign 96-99 percent of the marginal effects of mothers' education to mothers with 8 to 9 years of schooling, i.e. to mothers with basic track schooling (see Appendix Table B.7). Values below 100 percent may arise through measurement error in mothers' years of schooling.

${ }^{15}$ Calculations of counterfactual means for the treatment group are obtained from the following equation: $E\left(H_{i} \mid Z_{i}=1\right.$, mother from low track $)-\hat{\gamma_{1}}$. For smoking, $E\left(H_{i} \mid Z_{i}=1\right.$, mother from low track $)=$ .204 ; for overweight, $E\left(H_{i} \mid Z_{i}=1\right.$, mother from low track $)=.134$. 
I also estimate the effect on children's obesity (BMI above the 95th percentile, based on Kromeyer-Hauschild et al., 2001). IV-estimates are imprecise, but the reduced form estimates suggest a significant reduction in adolescents' obesity of 2.6 percentage points (column 8). With respect to offspring's BMI, the reform estimates are negative, but insignificant. This may be related to increases in the BMI at the bottom of the BMI distribution, and reductions in the probability that children are underweight. The IVestimate on being underweight indeed points to such a reduction, but it is imprecisely estimated (column 9-10).

The effects on smoking and overweight may vary by children's gender. Boys typically react more strongly to changes in early childhood conditions (e.g. Waldfogel, 2006), which may also relate to changes in maternal schooling. This is particularly true for children from lower socio-economic backgrounds (e.g. Autor, Figlio, Karbownik, Roth, and Wasserman, 2016). In Table 4, I report estimates of gender-specific treatment effects, interacting the treatment dummy with gender dummies. The increase in maternal compulsory schooling reduces girls' and boys' smoking probability, but the reduction is stronger for boys (column 1). With respect to being overweight, the effect on girls is slightly larger but not statistically different from the effect on boys (column 2). In Table 4, I report further effect estimates for children from families with household income below and above the median, from single mothers and both parents, from smoking and non-smoking mothers, as well as from overweight and non-overweight mothers, but there are no significant differences between these groups. If at all, the effects on smoking appear larger for children from households with incomes below the median $(\mathrm{p}$-value $=0.18) \cdot{ }^{16}$

Does paternal schooling also improve offspring's health behaviours and health status? I turn to this question in Table 5 and analyse the same sample of children, now basing the analysis on their fathers born between 1930 and 1960 .

\footnotetext{
${ }^{16}$ The estimations also include the respective group dummy. The effect estimates are only unbiased if family income, single motherhood, mothers' smoking behaviour and overweight are not affected by the compulsory schooling reform. I provide evidence for this in Section D.
} 
In column 1, I report the reform effect of the introduction of a ninth grade on fathers' years of schooling. In both samples on children's outcomes, the estimated coefficients suggest an increase of 0.53-0.56 years. As for mothers, there is no evidence for reform effects on the highest completed school track of fathers (column 2). While OLS-estimates suggest that paternal schooling reduces children's smoking and being overweight (column 3), IV-estimates swap the sign of the relationship and turn insignificant (column 4). The reduced form effect of the introduction of a ninth grade in the subsample of children with fathers from the (treated) basic school track produces similar result (column 5). Effects in the subsample of children with untreated fathers from higher tracks are expectedly close to zero and insignificant (column 6$).{ }^{17}$

Within compulsory schooling changes, the limited impact of fathers' schooling on children's outcomes has been documented in other contexts as well. For example, Holmlund et al. (2011) and Lundborg et al. (2014) do not find evidence of effects on children's schooling and general health if fathers are affected by increases in compulsory schooling.

\section{Parental schooling and children's health-related outcomes in adulthood}

Both smoking and being overweight in adolescence are highly predictive of related unhealthy behaviours and chronic conditions later in life (e.g. Guo, Wu, Chumlea, and Roche, 2002; Jürges and Meyer, 2017). Therefore, improvements in adolescent health behaviours and health status should persist into adulthood, eventually resulting in better long-term health. In order to examine the long-term effects of intergenerational education transmission, I draw a sample of individuals aged 30 to 50 from the German SOEP data. ${ }^{18}$ I employ the same empirical strategy as outlined in eq. 3 and restrict the sample again to children of parents born between 1930 and 1960. Individuals providing the necessary

\footnotetext{
${ }^{17}$ I also check for heterogeneous effects of paternal schooling on girls and boys, but cannot find any evidence.

${ }^{18}$ To maximise the sample size, I use children-reported information on parental birth year and highest level of education if it is not reported by parents themselves. I restrict the sample to individuals below age 50 in order to reduce the risk of endogenous sample selection that may result from maternal schooling effects on children's longevity.
} 
information at different ages are included repeatedly to increase the sample size and the precision of the estimates. Inference is based on robust standard errors clustered at the state by parental year of birth level.

The results are reported in Table 6. Panel A shows that children of affected mothers are significantly less likely to smoke (column 1), mostly because they never initiated smoking (columns 2-3, based on a smaller sample as information on quitting and never-smoking is only available in fewer waves). In addition, children also have a lower BMI and a lower probability of being overweight (columns 4-5). As smoking and being overweight can cause severe chronic conditions, I test whether children of treated mothers are eventually less likely to suffer from chronic conditions later in life. I find evidence of a significant reduction (column 6). Children also report an improved general health status (column 7). ${ }^{19}$ There are no such effects in the placebo sample of children with mothers from higher school tracks. As with adolescents, there are also no effects of paternal increases in compulsory schooling on children's health-related outcomes (see Panel B of Table 6). The results show that health-related behaviours are already determined early in life by maternal schooling. It also shows that increased maternal schooling reduces the socioeconomic gap in health conditions.

\section{Potential channels}

What explains the substantial effects of increases in maternal schooling on children's health behaviours and health status? I focus the analysis on changes in children's human capital, their peer environment and family characteristics (family income, mating, family stability, fertility, as well as parental health status and health behaviours).

Children's human capital. I build on the theoretical framework by Cunha and Heck-

\footnotetext{
${ }^{19}$ The outcome "chronic condition" is based on the survey question "Have you been suffering from any conditions or illnesses for at least one year or chronically?"; the outcome "general health" is based on "How would you describe your current health?" (measured in five categories ranging from very good to bad, rescaled such that higher values indicate better outcomes). "General health" is standardised to have a mean of zero and a standard deviation of one.
} 
man (2007) and Heckman (2007) on the dynamic formation of human capital. In this framework, human capital is multidimensional and results from a multistage production technology. Improvements in earlier human capital, e.g. in the form of better health at birth, foster the development of later human capital (self-productivity). Moreover, increased human capital in early stages of life make investments in later periods more productive (dynamic complementarities). Currie and Moretti (2003) show that increases in maternal education in the US (caused by opening new colleges) improve prenatal care, lower smoking during pregnancy, increase gestational age, and reduce the risk of low birth weights. Further, Chou et al. (2010) show that increases in maternal education lower the incidence of low birth weights and infant mortality in Taiwan. ${ }^{20}$ This may immediately reduce the inherent disadvantage that children are born with. Behrman and Rosenzweig (2004) and Black et al. (2007) show that low birth weights affect outcomes in adulthood, resulting in lower educational attainments and lower earnings. Case et al. (2005) show that poor health during childhood is associated with lower educational attainment, poorer health, and lower social status in adulthood.

Consequently, improvements in early health may improve other human capital dimensions. With dynamic complementarities, healthier children may benefit more from schooling. Indeed, numerous studies provide evidence that increases in maternal education increase the educational attainments of their children (e.g. Oreopoulos et al., 2006; Maurin and McNally, 2008; de Haan, 2011; Holmlund et al., 2011; Chevalier, Harmon, O' Sullivan, and Walker, 2013; Piopiunik, 2014). Increases in children's educational attainments, in turn, improve cognition (helping them process health-related information) and earnings prospects. These factors increase the costs of engaging in unhealthy behaviours, whose reductions ultimately improve long-term health (e.g. Grossman, 2006; Cutler and LlerasMuney, 2010). ${ }^{21}$

\footnotetext{
${ }^{20} \mathrm{McCrary}$ and Royer (2011) cannot find such effects using school entry policies as an instrument for schooling. However, the authors cannot rule out that maternal schooling effects on infant health are heterogeneous and not captured by their instrument.

${ }^{21}$ Increased education may also impact time preferences and risk aversion which may be related to unhealthy behaviours (Fuchs, 1982; Becker and Mulligan, 1997). However, the empirical relevance of this
} 
To test whether maternal schooling affects children's human capital in my data, I analyse children's educational attainment as one important dimension of it. I observe whether adolescents attend the basic, middle or high school track. ${ }^{22}$ The school track is highly correlated with children's cognitive capabilities and earnings prospects: Dustmann and Schönberg (2011) report that the PISA scores in reading and mathematics of middle (high) track students are about 0.6 (1.5) standard deviations higher than those of children in the low track. They earn 24 (49) percent higher wages.

Indeed, the probability that children attend a higher track increases significantly if mothers are affected by the increase in compulsory schooling (column 1 of Table 7), mainly because children are more likely to attend the middle track rather than the low track (columns 2-3). Estimating the reform effect separately by gender suggests that the effect is stronger for boys (column 4), corroborating the evidence that boys from lower socio-economic backgrounds react more strongly to changes in early childhood conditions (Autor et al., 2016). These results are in line with Piopiunik (2014), who evaluates the effects of the same reform on children's school track choice in data from the German SOEP.

Children's peer environment. Improvements in children's school track also improve the peer environment. Children in Germany are ability-tracked into physically separated schools as early as age ten. The differences in health behaviours and human capital of the peer environment are substantial: Compared to children in the basic track, children from higher tracks are 46 percent less likely to smoke, 50 percent less likely to be overweight, and 2.6 times more likely to have parents with a university entrance qualification. ${ }^{23}$ These stark differences in the adolescent peer environment may play an important role in developing risky health behaviours. With respect to smoking, the large majority of individuals

\footnotetext{
channel appears small (e.g. Cutler and Lleras-Muney, 2010).

${ }^{22}$ Due to data limitations in early waves of the German Micro Census, I only reliably observe the (completed) school track at age 17 and 18, when children either completed schooling or are still enrolled to the final grades of academic track schools. I restrict the sample accordingly.

${ }^{23}$ Statistics are based on data from the German Micro Census and children in the analysed sample.
} 
who smoke initiate smoking while they are still in school. Most of the educational gradient in smoking already exists before compulsory education is completed (Jürges and Meyer, 2017). Powell, Tauras, and Ross (2005) show that school-level smoking rates play an important role for smoking initiation of adolescents. Moving students from a nonsmoking school to a school where 25 percent of students smoke increases their smoking probability by about 14.5 percentage points, ceteris paribus. Lundborg (2006) also provides evidence for substantial school-peer effects in smoking, binge drinking, and drug use. Peer effects are also identified for weight problems (Trogdon, Nonnemaker, and Pais, 2008; Carrell, Hoekstra, and West, 2011) and related behaviours such as sports, exercise, and unhealthy diets (Ali, Amialchuk, and Heiland, 2011). Consequently, the tracking system may amplify improvements in early human capital and schooling resulting from increases in maternal schooling.

Family income and mating. ${ }^{24}$ Numerous studies document a strong family income gradient in child health-related behaviours (e.g. Soteriades and DiFranza, 2003) and health (e.g. Case, Lubotsky, and Paxson, 2002; Currie and Stabile, 2003). Higher family income allows parents to purchase better health services for their children as well as to invest in healthier lifestyles or safer and healthier environments. However, increased income may be less important in countries with almost universal health care that is of low private cost. Reinhold and Jürges (2012) find only weak evidence for a causal effect of parental income on child health in Germany, Kuehnle (2014) finds only small effects for the UK.

To investigate the role of the family income channel in my setting, I first estimate reduced form effects on maternal labour market outcomes (Panel A of Table 8). Affected mothers have a 1.5 percentage points higher probability to work and wages increase by 0.5 percent. ${ }^{25}$ These small effects are in line with the zero-returns to compulsory schooling in

\footnotetext{
${ }^{24}$ For the following analyses, I use the same Micro Cencus waves as in the main analysis and include mothers with basic track schooling of all children aged 18 or younger to increase the sample size.

${ }^{25}$ For the calculation of maternal log hourly wage I divide the net monthly income by the weekly working hours times 4.3, as in Pischke and von Wachter (2008). The log wage of non-working mothers is set to zero.
} 
Pischke and von Wachter (2008) and Kamhöfer and Schmitz (2016). The authors argue that basic track students already learned labour market-relevant skills earlier.

In Panel B, I examine the reform effects on maternal mating behaviour. Treated mothers mate slightly older men with 0.23 more years of schooling. The increase in partners' years of schooling is largely related to partners also being affected by changes in compulsory schooling. The reform has no impact on the highest school degree of the partner, on the employment probability, or on earnings. The absence of labour market returns is not surprising given that the increase in partners' schooling stems from increases in compulsory schooling that did not generate significant labour market returns. Note, however, that the estimates are only informative on changes in family income, but not on the allocation of income. Affected mothers could still allocate more family income towards health-related inputs (Grossman, 1972). For example, mothers may provide healthier food for their children, invest in physical activity, or move to better neighbourhoods.

Family stability and fertility. Family disruptions can cause stress and make children more likely to initiate smoking (Francesconi et al., 2010) or to become overweight (Schmeer, 2012). I find no evidence for a reform effect on the probability of living with a single mother or of being married. Another potential explanation relates to fertility effects of education. If more schooling reduces the number of children or increases the age at birth, more resources may be allocated to a child (e.g., Hanushek, 1992). I find some evidence for effects on the number of children living in the household, pointing to fertility effects of the compulsory schooling reform. The effect estimate on maternal age when giving birth is slightly positive, but insignificant. The fertility effects are consistent with McCrary and Royer (2011), Cygan-Rehm and Maeder (2013), and Lundborg et al. (2014). The effects are also consistent with the quantity-quality trade-off theory. According to this theory, better educated parents invest more resources in the human capital of fewer children. $^{26}$

\footnotetext{
${ }^{26}$ Substantial effects of education on fertility may induce an endogeneity problem, as selection into motherhood may confound the sample. This feature is shared by nearly all studies on intergenerational
} 
Parental health status and health behaviours. An important explanation for children's health is seen in the health status and health-related behaviours of parents who may serve as role models (e.g. Powell and Chaloupka, 2005; Loureiro, Sanz-De-Galdeano, and Vuri, 2010; Göhlmann, Schmidt, and Tauchmann, 2010). In Panel D, I analyse effects on the mother's own smoking behaviour and that of her partner, and cannot find any evidence. Potentially, this is because the introduction of a ninth school year affected children at a time when they had already initiated smoking. Moreover, most cohorts may have started smoking before the dangers of smoking became publicly recognized following the 1964 reports of the US Surgeon General on the harms of smoking (Lochner, 2011). The findings correspond to Kemptner et al. (2011), who evaluate the direct health effects of the reform. With respect to parental weight problems, I do not find evidence for effects on mothers' BMI and being overweight, but there is a reduction in the probability that the partner is overweight (Panel E).

In sum, the effects of increased maternal schooling on children's smoking and overweight are best explained by taking a dynamic perspective on human capital formation, including self-productivity of human capital and dynamic complementarity. Parents invest more in children's human capital (likely already improving early health outcomes ) which improves children's schooling attainments. Resulting better cognition and earnings prospects may increase the costs of unhealthy behaviours. The effects are amplified by the tracking system, which exhibits a strong gradient in peer's health behaviours in adolescence - a sensitive developmental period. Improvements in the family environment (i.e. in terms of family income, mating, family stability, household size, and parental health behaviours) appear small overall. One explanation may be that the employed measures are not differentiated enough. For example, despite only small effects on parental health behaviours, parents may still be more aware of the negative consequences of unhealthy behaviours, thus encouraging children's physical activity, improving children's diet, or imposing smok-

effects of schooling that also document effects on fertility as in, e.g., Carneiro et al. (2013) and Lundborg et al. (2014). 
ing rules at home (Powell and Chaloupka, 2005). Additionally, the parent-child relationship may have changed, which can play a role in the prevention of risky health behaviours (Powell and Chaloupka, 2005). With a dynamic human capital production function in mind, even small changes in these dimensions may contribute to substantial improvements in health behaviours and long-term human capital. ${ }^{27}$

\section{Robustness checks}

\section{A. Identification assumptions}

At the heart of the identification strategies is the common trend assumption: States that introduced the compulsory schooling reform would have developed similarly over time with respect to children's outcomes as states that did not (yet) increase compulsory schooling. I perform several tests to check whether this assumption is plausible.

Throughout the analysis, I demonstrate that children's smoking behaviour and overweight only improve if mothers indeed attended the affected basic school track, assuring that the model is not just capturing general trends. In further checks on the common trend assumption, I simulate placebo reforms (Panel A of Table 9). I drop children with treated mothers from the sample and assume that the compulsory schooling reform was implemented two to five years before the actual reform. ${ }^{28}$ The coefficient estimates vary around zero with changes in their sign and are statistically insignificant. The smaller sample size, however, increases the noise in the estimates.

Alternatively, I check whether the econometric model captures effects on health-related outcomes that should not be affected by changes in compulsory schooling (Panel B of

\footnotetext{
${ }^{27}$ When I add the school track as a control variable to the main estimations, the coefficient on an additional year of schooling of the mother does not change significantly. I interpret this as evidence that the effect of maternal education on children's health behaviours works through a multiplicity of factors, is likely dynamic, and can only insufficiently be captured by the school track serving as a proxy for individual's human capital.

${ }^{28} \mathrm{~A}$ placebo reform in the year preceding the actual reform may be confounded by grade repeaters and late school entry.
} 
Table 9). One such placebo outcome could be body height in adulthood, which is largely determined by genetic factors in high-income countries (Silventoinen, 2003). I estimate the effect on adult children in the SOEP data (as in Section IV.C) for children with mothers from the basic track. ${ }^{29}$ The coefficient estimate is very small and insignificant, suggesting that effects related to children's BMI result from changes in more malleable body weight rather than mostly genetically determined body height.

As the common trend assumption is conditional on covariates, I assess the sensitivity of the estimates to varying sets of covariates (columns 2-8 of Table 10): I first drop the X-variables (gender, children's age, survey wave); I add controls for states' GDP and unemployment rate when children are aged 18 to account for differential state trends; I drop state controls and state-specific time trends (X-variables put back in); I include two dummies in the main specification to indicate cohorts that were exposed to short/long school years when the national school calendar was harmonized around 1966 (for reform details, see Pischke, 2007); I include two dummies for cohorts potentially affected by region-specific or temporary school year increases before the general increase in compulsory schooling was mandated (see Section II for details); I substitute the linear trend in mothers' year of birth with a linear trend in children's year of birth; and I include both linear trends in children's and mothers' year of birth. Across the specifications, the IV-estimates and reduced form estimates are very stable, and none of the estimated coefficients are statistically different from the main estimates.

In another set of tests on the common trend assumption, I employ models that rest on alternative identification assumptions. First, I use the idea of a regression discontinuity design (column 9): I centre the sample 15 years before and after the respective reforms and allow for a linear trend in the maternal year of birth for children's outcomes in each federal state. This trend is allowed to jump with the increase in mothers' compulsory schooling. The resulting IV-estimates are similar to the main effects. Reduced form

\footnotetext{
${ }^{29}$ I use the sample of adult children rather than adolescents because smoking can stunt growth in adolescence (e.g. Stice and Martinez, 2005).
} 
estimates are smaller, but in the confidence band of the main estimates. Perhaps due to the parsimonious model, the effect on children being overweight turns just insignificant $(p=0.11)$. Note, however, that regression discontinuity designs likely underestimate the long-term benefits of education if outcomes are impacted by spill-overs from other cohorts (which is likely the case for health-related outcomes, see Lochner, 2011).

Alternatively, state-specific smoking regulations, education policies, overweight campaigns, or macro-economic conditions may create non-linear regional trends in children's outcomes. These factors are shared by all children in the same federal state, no matter whether their mother attended the basic track or higher tracks. I use children with mothers from higher tracks as an additional control group in a difference-in-differencesin-differences model. The estimates are very similar to the main results (column 10). ${ }^{30}$

Finally, I check on omitted trends graphically. I calculate residuals from the differencein-differences models with the treatment dummy added back in. Figure A.2 plots average residuals by the distance of mothers' cohorts to the compulsory schooling reform in their federal state. Systematic time trends that were not captured by the difference-indifferences model would be revealed in the residuals. This is not the case: Before the introduction of the reform, the residuals vary around zero. After the reform, they are constantly below zero for children of mothers from the basic track. In the placebo sample of children with mothers from higher tracks, the residuals continuously vary around zero.

\section{B. Sample choices and weighting}

The analysis requires decisions on the selected main sample. I perform checks on the sensitivity of the main results to changes in the sample choice (see Appendix Table B.9).

While I restrict the main sample to children of mothers born between 1930 and 1960, I could also centre the sample around the reforms, as employed by, e.g., Brunello, Fort, and

\footnotetext{
${ }^{30} \mathrm{IV}$-estimates are identical to the reduced form estimates because maternal years of schooling are generated based on their school degree, such that the first stage in the sample of basic-track mothers is one, and zero in the sample of mothers from higher tracks.
} 
Weber (2009). In columns 2-7 of Table B.9, I include children of mothers born 10 to 15 years before and after the increase in compulsory schooling. I obtain similar estimates.

Next, I remove certain states and cohorts. In the analysis, I assume that parents went to school in the state they are currently living in. Cross-state mobility is generally low in Germany: 85 percent of adults in their 40s are still living in the same state where they went to school. This number is smaller in city-states (in the present sample Hamburg, 63 percent, and Bremen, 70 percent). Removing observations from these states yields similar results (column 8). Furthermore, a lagged roll-out of the programme within certain regions of the federal states, as well as early school entry of parents may introduce some fuzziness in the treatment assignment around the reform introduction. Dropping maternal cohorts that should have been treated first results in the same conclusions (column 9).

The data on children's smoking behaviour (overweight) was only collected in the German Micro Census from 1989 (1999) onward. Therefore, the probability of observing younger cohorts of mothers is higher. In Panel A of Figure A.3, I plot the frequency with which mothers' birth cohorts appear in the main sample, and the original frequency of female births in the population (based on the German Micro Census 1989). Similarly, the overweight-sample over-represents mothers giving birth at older ages (Panel B of Figure A.3, based on the full sample from the German Micro Census of children aged 0-18 living with their parents). I run the main analysis using inverse probability weights to match the population frequencies on mothers' year of birth and age at birth as plotted in Figure A.3 (see Table B.10). Assigning higher weights to cohorts with few observations and less informational content, and lower weights to cohorts with more observations, increases the noise in some estimates. In the sample containing children's weight information, I remove the small number of mothers born before 1940 to reduce this noise. Overall, the results are equivalent to the main findings. ${ }^{31}$

\footnotetext{
${ }^{31}$ To reassure that selective moving-out of adolescent children is not confounding the results, I also estimate effects separately for children aged 15-16, who are almost exclusively in education and still living with their parents, and for children aged 17-18 (Table B.8). Effects on smoking behaviour are slightly smaller for children aged 15-16 (although not significantly), which may relate to lower smoking
} 


\section{Conclusion}

This paper traces the effects of an increase in compulsory schooling in Germany on children's health behaviours and long-term health. Mothers' increase in schooling substantially reduces children's probability to smoke and to be overweight in adolescence and adulthood. The findings pass a large set of robustness and placebo checks. For fathers, I do not find such effects. The effects on children's health-related outcomes are likely a product of a multiplicity of factors, including improvements in early childhood health, better schooling attainment, improved cognition, and a better peer environment in adolescence. Improvements in the family environment, including family income, mating, family stability, household size, and parental health behaviours, appear small overall. Still, in a dynamic framework of human capital formation, even small changes in these dimensions may contribute to substantial improvements in health behaviours and long-term human capital.

Since 2000, there has been a substantial reduction in teenage smoking rates in high income countries (e.g. WHO, 2015). In the same time period, women significantly increased their education levels (e.g. OECD, 2015). My findings suggest that the increase in female education is causally related to the reduction in teenage smoking rates. If we assume a homogeneous treatment effect of mothers' education on children's health behaviours, back-of-the-envelope calculations suggest that increases in female schooling account for approximately thirty percent of the reduction in teenage smoking rates. ${ }^{32}$ With respect to increases in overweight and obesity that can be observed globally, increases in maternal

rates at younger ages. Effects on being overweight are very similar to the main results, but smaller subsamples increase the sensitivity to including state-specific time trends and reduce the precision of the estimates.

${ }^{32}$ Between 1999 and 2009, the total years of schooling of mothers in my sample increased by approximately 1.5 years because the share of women in the basic track declined as capacities in higher school tracks increased (see, e.g., Jürges, Reinhold, and Salm, 2011). The share of women with college education also increased. Over the same time period, the teen smoking rate declined by approximately 13 percentage points (Federal Center for Health Education, 2011). The back-of-the-envelope estimation considers the conservative point estimate as described in Section IV, i.e. 2.6 percentage points $\times 1.5$ years / 13 percentage points $=0.3$. 
schooling still have a protective effect on children's weight problems.

While this study establishes a causal link for long-term effects of parental education on children's health, the analysis also has some limitations. One should bear in mind that the results apply to children of parents with rather low levels of education (although more than half of the parents attended this track). If we expect the benefits of schooling to be larger for lower levels of education (Imbens and Angrist, 1994), the estimates should be interpreted as an upper-bound. Future research should try to identify effects in higher parts of the parental education distribution. Additionally, the proposed mechanisms deserve further investigation. An exciting, though challenging, avenue for future research is to better understand how parental education impacts children's health. A major challenge will be to acquire detailed information on, e.g., parental inputs around birth and throughout childhood, on peers of children together with exogenous variation in parental education or on child-parent relationships.

The paper contributes to our understanding of the link between education and health, suggesting that a substantial portion of the causal relationship is overlooked if intergenerational effects are not considered. The results show that the impact of maternal education on health behaviours and health is an important mechanism through which economic status is transmitted. The paper significantly contributes to our understanding of non-market benefits of education. While the literature cannot typically disentangle the effects of education from effects of higher incomes, I provide evidence from a setting in which the income channel is mostly closed. The paper also improves our understanding of long-term effects of educational interventions that strengthen the case for public investments in general education. 


\section{References}

Ali, M. M., A. Amialchuk, and F. W. Heiland (2011). Weight-related behavior among adolescents: The role of peer effects. PLoS ONE 6(6), e21179.

Autor, D., D. Figlio, K. Karbownik, J. Roth, and M. Wasserman (2016). Family disadvantage and the gender gap in behavioral and educational outcomes. NBER Working Paper Series 22267, National Bureau of Economic Research.

Baum, C. L. and C. J. Ruhm (2009). Age, socioeconomic status and obesity growth. Journal of Health Economics 28(3), 635-648.

Becker, G. S. and C. B. Mulligan (1997). The endogenous determination of time preference. Quarterly Journal of Economics 112(3), 729-758.

Behrman, J. R. and M. R. Rosenzweig (2004). Returns to birthweight. Review of Economics and Statistics 86(2), 586-601.

Bingley, P. and A. Martinello (2017). Measurement error in income and schooling, and the bias of linear estimators. Journal of Labor Economics, forthcoming.

Black, S. E., P. J. Devereux, and K. G. Salvanes (2005). Why the apple doesn't fall far: Understanding intergenerational transmission of human capital. American Economic Review 95(1), 437-449.

Black, S. E., P. J. Devereux, and K. G. Salvanes (2007). From the cradle to the labor market? The effect of birth weight on adult outcomes. Quarterly Journal of Economics 122(1), 409-439.

Brunello, G., M. Fort, and G. Weber (2009, mar). Changes in compulsory schooling, education and the distribution of wages in Europe. Economic Journal 119(536), 516539.

Cameron, A. C., J. B. Gelbach, and D. L. Miller (2008). Bootstrap-based improvements for inference with clustered errors. Review of Economics and Statistics 90(3), 414-427.

Carneiro, P., C. Meghir, and M. Parey (2013). Maternal education, home environments, and the development of children and adolescents. Journal of the European Economic Association 11(SUPPL. 1), 123-160.

Carrell, S. E., M. Hoekstra, and J. E. West (2011). Is poor fitness contagious? Evidence from randomly assigned friends. Journal of Public Economics 95(7-8), 657-663.

Case, A., A. Fertig, and C. Paxson (2005). The lasting impact of childhood health and circumstance. Journal of Health Economics 24(2), 365-389.

Case, A., D. Lubotsky, and C. Paxson (2002). Economic status and health in childhood: The origin of the gradient. American Economic Review 92(5), 1308-1334. 
Cawley, J. and C. J. Ruhm (2011). The economics of risky health behaviors. In M. V. Pauly, T. G. Mcguire, and P. P. Barros (Eds.), Handbook of Health Economics, Volume 2, Chapter 3, pp. 95-199. Amsterdam: North Holland.

Cawley, J. and C. K. Spiess (2008). Obesity and skill attainment in early childhood. Economics \& Human Biology 6(3), 388-397.

Chevalier, A., C. Harmon, V. O' Sullivan, and I. Walker (2013). The impact of parental income and education on the schooling of their children. IZA Journal of Labor Economics $2(1), 8$.

Chou, S.-Y., J.-T. Liu, M. Grossman, and T. Joyce (2010). Parental education and child health: Evidence from a natural experiment in Taiwan. American Economic Journal: Applied Economics 2(1), 33-61.

Clark, D. and H. Royer (2013). The effect of education on adult mortality and health: Evidence from Britain. American Economic Review 103(6), 2087-2120.

Cole, T. J., M. C. Bellizzi, K. M. Flegal, and W. H. Dietz (2000). Establishing a standard definition for child overweight and obesity worldwide: international survey. British Medical Journal 320(7244), 1240-1240.

Cunha, F. and J. J. Heckman (2007). The technology of skill formation. American Economic Review 97(2), 31-47.

Currie, J. and E. Moretti (2003). Mother's education and the intergenerational transmission of human capital: Evidence from college openings. Quarterly Journal of Economics 118(4), 1495-1532.

Currie, J. and M. Stabile (2003). Socioeconomic status and child health: Why is the relationship stronger for older children? American Economic Review 93(5), 18131823.

Cutler, D. M. and A. Lleras-Muney (2010). Understanding differences in health behaviors by education. Journal of Health Economics 29(1), 1-28.

Cygan-Rehm, K. and M. Maeder (2013). The effect of education on fertility: Evidence from a compulsory schooling reform. Labour Economics 25, 35-48.

de Haan, M. (2011). The effect of parents' schooling on child's schooling: A nonparametric bounds analysis. Journal of Labor Economics 29(4), 859-892.

Dickson, M., P. Gregg, and H. Robinson (2016). Early, late or never? When does parental education impact child outcomes? Economic Journal 126(596), F184-F231.

Dustmann, C. (2004). Parental background, secondary school track choice, and wages. Oxford Economic Papers 56(2), 209-230.

Dustmann, C. and U. Schönberg (2011). Expansions in maternity leave coverage and children's long-term outcomes. American Economic Journal: Applied Economics 4(3), $190-224$. 
Federal Center for Health Education (2011). Der Tabakkonsum Jugendlicher und junger Erwachsener in Deutschland 2010: Ergebnisse einer aktuellen Repräsentativbefragung und Trends. Köln: Bundeszentrale für gesundheitliche Aufklärung.

Francesconi, M., S. P. Jenkins, and T. Siedler (2010). Childhood family structure and schooling outcomes: Evidence for Germany. Journal of Population Economics 23(3), 1073-1103.

Fuchs, V. R. (1982). Time preference and health: An exploratory study. In V. Fuchs (Ed.), Economic Aspects of Health, pp. 93-120. Chicago: University of Chicago Press.

Göhlmann, S., C. M. Schmidt, and H. Tauchmann (2010). Smoking initiation in Germany: The role of intergenerational transmission. Health Economics 19(2), 227-242.

Grossman, M. (1972). On the concept of health capital and the demand for health. Journal of Political Economy 80(2), 223-255.

Grossman, M. (2006). Education and nonmarket outcomes. In E. Hanushek and F. Welch (Eds.), Handbook of the Economics of Education, Volume 1, Chapter 10, pp. 577-633. Amsterdam: North Holland.

Grossman, M. (2015). The relationship between health and schooling. Nordic Journal of Health Economics 3(1), 7-17.

Guo, S. S., W. Wu, W. C. Chumlea, and A. F. Roche (2002). Predicting overweight and obesity in adulthood from body mass index values in childhood and adolescence. American Journal of Clinical Nutrition 76 (3), 653-658.

Hanushek, E. (1992). The trade-off between child quality and quantity. Journal of Political Economy 100(1), 84-117.

Heckman, J. J. (2007). The economics, technology, and neuroscience of human capability formation. Proceedings of the National Academy of Sciences 104 (33), 13250-13255.

Hill, J. O. (1998). Environmental contributions to the obesity epidemic. Science $280(5368), 1371-1374$.

Hill, J. O. (2003). Obesity and the environment: Where do we go from here? Science 299 (5608), 853-855.

Holmlund, H., M. Lindahl, and E. Plug (2011). The causal effect of parents' schooling on children's schooling: A comparison of estimation methods. Journal of Economic Literature $49(3), 615-651$.

Imbens, G. W. and J. D. Angrist (1994). Identification and estimation of local average treatment effects. Econometrica 62(2), 467.

Janssen, I., P. T. Katzmarzyk, W. F. Boyce, C. Vereecken, C. Mulvihill, C. Roberts, C. Currie, and W. Pickett (2005). Comparison of overweight and obesity prevalence in school-aged youth from 34 countries and their relationships with physical activity and dietary patterns. Obesity Reviews 6(2), 123-132. 
Jürges, H. and S.-C. Meyer (2017). Educational differences in smoking: Selection versus causation. Schumpeter Discussion Papers 17001, University of Wuppertal.

Jürges, H., S. Reinhold, and M. Salm (2011). Does schooling affect health behavior? Evidence from the educational expansion in Western Germany. Economics of Education Review 30(5), 862-872.

Kamhöfer, D. A. and H. Schmitz (2016). Reanalyzing zero returns to education in Germany. Journal of Applied Econometrics 31(5), 912-919.

Kemptner, D., H. Jürges, and S. Reinhold (2011). Changes in compulsory schooling and the causal effect of education on health: Evidence from Germany. Journal of Health Economics 30(2), 340-354.

Kemptner, D. and J. Marcus (2013). Spillover effects of maternal education on child's health and health behavior. Review of Economics of the Household 11(1), 29-52.

Kenkel, D., D. Lillard, and A. Mathios (2006). The roles of high school completion and GED receipt in smoking and obesity. Journal of Labor Economics 24(3), 635-660.

Kromeyer-Hauschild, K., M. Wabitsch, D. Kunze, F. Geller, H. C. Geiß, V. Hesse, A. von Hippel, U. Jaeger, D. Johnsen, W. Korte, K. Menner, G. Müller, J. M. Müller, A. Niemann-Pilatus, T. Remer, F. Schaefer, H.-U. Wittchen, S. Zabransky, K. Zellner, A. Ziegler, and J. Hebebrand (2001). Percentiles of body mass index in children and adolescents evaluated from different regional German studies. Monatsschrift Kinderheilkunde 149(8), 807-818.

Kuehnle, D. (2014). The causal effect of family income on child health in the UK. Journal of Health Economics 36(1), 137-150.

Kurth, B.-M. (2007). Der Kinder- und Jugendgesundheitssurvey (KiGGS): Ein Überblick über Planung, Durchführung und Ergebnisse unter Berücksichtigung von Aspekten eines Qualitätsmanagements. Bundesgesundheitsblatt - Gesundheitsforschung - Gesundheitsschutz 50(5-6), 533-546.

Lindeboom, M., A. Llena-Nozal, and B. van der Klaauw (2009). Parental education and child health: Evidence from a schooling reform. Journal of Health Economics 28(1), 109-131.

Lochner, L. J. (2011). Nonproduction benefits of education: Crime, health, and good citizenship. In E. A. Hanushek, S. Machin, and L. Woessmann (Eds.), Handbook of the Economics of Education, Volume 4, Chapter 2, pp. 182-262. Amsterdam: North Holland.

Løken, K. V., M. Mogstad, and M. Wiswall (2012). What linear estimators miss: The effects of family income on child outcomes. American Economic Journal: Applied Economics 4(2), 1-35.

Loureiro, M. L., A. Sanz-De-Galdeano, and D. Vuri (2010). Smoking habits: Like father, like son, like mother, like daughter? Oxford Bulletin of Economics and Statistics 72(6), $717-743$. 
Lowry, R., L. Kann, and J. L. Collins (1996). The effect of socioeconomic status on chronic disease risk behaviors among US adolescents. JAMA: The Journal of the American Medical Association 276(10), 792.

Lundborg, P. (2006). Having the wrong friends? Peer effects in adolescent substance use. Journal of Health Economics 25(2), 214-233.

Lundborg, P., A. Nilsson, and D.-O. Rooth (2014). Parental education and offspring outcomes: Evidence from the Swedish compulsory school reform. American Economic Journal: Applied Economics 6(1 A), 253-278.

Maurin, E. and S. McNally (2008). Vive la révolution! Long-term educational returns of 1968 to the angry students. Journal of Labor Economics 26(1), 1-33.

Mazumder, B. (2012). The effects of education on health and mortality. Nordic Economic Policy Review 1, 261-301.

McCrary, J. and H. Royer (2011). The effect of female education on fertility and infant health: Evidence from school entry policies using exact date of birth. American Economic Review 101(1), 158-195.

Must, A. (1999). The disease burden associated with overweight and obesity. JAMA 282(16), 1523.

OECD (2015). Education at a glance 2015: OECD indicators. Paris: OECD Publishing.

Oreopoulos, P., M. E. Page, and A. H. Stevens (2006). The intergenerational effects of compulsory schooling. Journal of Labor Economics 24(4), 729-760.

Oreopoulos, P. and K. G. Salvanes (2011). Priceless: The nonpecuniary benefits of schooling. Journal of Economic Perspectives 25(1), 159-184.

Petzold, H.-J. (1981). Schulzeitverlängerung: Parkplatz oder Bildungschance? Bensheim: Päd. extra Buchverlag.

Piopiunik, M. (2014). Intergenerational transmission of education and mediating channels: Evidence from a compulsory schooling reform in Germany. Scandinavian Journal of Economics 116(3), 878-907.

Pischke, J.-S. (2007). The impact of length of the school year on student performance and earnings: Evidence from the German short school years. Economic Journal 117(523), $1216-1242$.

Pischke, J.-S. and T. von Wachter (2005). Zero returns to compulsory schooling in Germany: Evidence and interpretation. IZA Discussion Paper Series 1645, Institute for the Study of Labor.

Pischke, J.-S. and T. von Wachter (2008). Zero returns to compulsory schooling in Germany: Evidence and interpretation. Review of Economics and Statistics 90 (3), 592-598.

Powell, L. M. and F. J. Chaloupka (2005). Parents, public policy, and youth smoking. Journal of Policy Analysis and Management 24(1), 93-112. 
Powell, L. M., J. A. Tauras, and H. Ross (2005). The importance of peer effects, cigarette prices and tobacco control policies for youth smoking behavior. Journal of Health Economics 24(5), 950-968.

RDC (2017). Mikrozensus der Jahre 1989, 1995, 1999, 2003, 2005, 2009. Datensätze. Research Data Centres of the Federal Statistical Office and the Statistical Offices of the Länder.

Reinhold, S. and H. Jürges (2012). Parental income and child health in Germany. Health Economics 21(5), 562-579.

Riphahn, R. T. and P. Trübswetter (2013). The intergenerational transmission of education and equality of educational opportunity in East and West Germany. Applied Economics 45(22), 3183-3196.

Schmeer, K. K. (2012). Family structure and obesity in early childhood. Social Science Research 41(4), 820-832.

Schneider, F. (1952). Das neunte Schuljahr. Stuttgart: Verlag Reinhold A. Müller.

Siedler, T. (2010). Schooling and citizenship in a young democracy: Evidence from postwar Germany. Scandinavian Journal of Economics 112(2), 315-338.

Silventoinen, K. (2003). Determinants of variation in adult body height. Journal of Biosocial Science 35(2), 263-285.

Soteriades, E. S. and J. R. DiFranza (2003). Parent's socioeconomic status, adolescents' disposable income, and adolescents' smoking status in Massachusetts. American Journal of Public Health 93(7), 1155-1160.

Stephens, M. and D.-Y. Yang (2014). Compulsory education and the benefits of schooling. American Economic Review 104(6), 1777-1792.

Stice, E. and E. E. Martinez (2005). Cigarette smoking prospectively predicts retarded physical growth among female adolescents. Journal of Adolescent Health 37(5), 363370.

Stolzenberg, H., H. Kahl, and K. E. Bergmann (2007). Körpermaße bei Kindern und Jugendlichen in Deutschland. Bundesgesundheitsblatt - Gesundheitsforschung - Gesundheitsschutz 50(5-6), 659-669.

Trogdon, J. G., J. Nonnemaker, and J. Pais (2008). Peer effects in adolescent overweight. Journal of Health Economics 27(5), 1388-1399.

Wagner, G. G., J. R. Frick, and J. Schupp (2007). The German Socio-Economic Panel Study (SOEP): Scope, evolution and enhancements. Schmollers Jahrbuch 127(1), 139169.

Waldfogel, J. (2006). What children need. Cambridge, MA: Havard University Press.

Waldron, I. and D. Lye (1990). Relationships of teenage smoking to educational aspirations and parents' education. Journal of Substance Abuse 2(2), 201-215. 
WHO (2009). Global health risks: Mortality and burden of disease attributable to selected major risks. Bulletin of the World Health Organization 87, 646-646.

WHO (2015). WHO global report on trends in tobacco smoking 2000-2025. Geneva: World Health Organization. 
Table 1: Reform effects on mothers' schooling

\begin{tabular}{lcc}
\hline & \multicolumn{2}{c}{ Sample } \\
\cline { 2 - 3 } Independent variable & $\begin{array}{c}\text { Currently smoking } \\
(1)\end{array}$ & $\begin{array}{c}\text { Overweight } \\
(2)\end{array}$ \\
\hline & Dep. variable: Mother's years of schooling (imp.) \\
\cline { 2 - 3 } Cohort with 9th grade in basic track & $0.6454^{* * *}$ & $0.4833^{* * *}$ \\
F-test: instrument=0 & $(0.0424)$ & $(0.1051)$ \\
& 231.21 & 21.16 \\
& Dep. variable: Mother with middle/high track \\
Cohort with 9th grade in basic track & schooling instead of basic track schooling \\
\cline { 2 - 3 } Sample mean & 0.0064 & 0.0007 \\
\hline Number of observations & $(0.0117)$ & $(0.0235)$ \\
& 0.54 & 12,794 \\
\hline
\end{tabular}

Notes: All OLS regressions also include the full set of mothers' year of birth dummies, federal state dummies, interactions of federal state dummies with a linear trend in mothers' year of birth, a dummy for female, dummies for children's age, dummies for the survey year and a quartic in mothers' age. Each coefficient is estimated in a separate regression. Standard errors are clustered at the federal state $\times$ mothers' birth year level and reported in parentheses. ${ }^{*} p<0.1,{ }^{* *} p<0.05,{ }^{* * *} p<0.01$. Source: RDC (2017), German Micro Census 1989, 1995, 1999, 2003, 2005, 2009, own calculations. 
Table 2: Effects of mothers' schooling on children's health-related outcomes

\begin{tabular}{|c|c|c|}
\hline \multirow[b]{2}{*}{ Independent variable } & \multicolumn{2}{|c|}{ Dependent variable (age $15-18$ ) } \\
\hline & $\begin{array}{l}\text { Child smokes } \\
\text { (1) }\end{array}$ & $\begin{array}{c}\text { Child is } \\
\text { overweight } \\
(2)\end{array}$ \\
\hline & \multicolumn{2}{|c|}{ Panel A: Full sample } \\
\hline & \multicolumn{2}{|c|}{ OLS estimates } \\
\hline Mothers' years of schooling (OLS) & $\begin{array}{c}-0.0216^{* * *} \\
(0.0018)\end{array}$ & $\begin{array}{c}-0.0188 * * * \\
(0.0016)\end{array}$ \\
\hline \multirow[t]{2}{*}{ Number of observations } & 27,339 & 12,794 \\
\hline & \multicolumn{2}{|c|}{ Instrumental variable estimates (IV) } \\
\hline Mothers' years of schooling (IV) & $\begin{array}{c}-0.0384^{* * *} \\
(0.0127)\end{array}$ & $\begin{array}{l}-0.0448^{*} \\
(0.0247)\end{array}$ \\
\hline \multirow[t]{3}{*}{ Number of observations } & 27,339 & 12,794 \\
\hline & \multicolumn{2}{|c|}{ Panel B: Reduced form estimates } \\
\hline & \multicolumn{2}{|c|}{ Subsample: Mothers from basic track } \\
\hline Mother's cohort with 9th grade in basic track & $\begin{array}{c}-0.0412^{* * *} \\
(0.0137)\end{array}$ & $\begin{array}{c}-0.0474^{* *} \\
(0.0193)\end{array}$ \\
\hline Sample mean & 0.18 & 0.13 \\
\hline \multirow[t]{2}{*}{ Number of observations } & 14,799 & 5,468 \\
\hline & \multicolumn{2}{|c|}{ Subsample: Mothers from middle/high tracks } \\
\hline Mother's cohort with 9th grade in basic track & $\begin{array}{c}0.0016 \\
(0.0136)\end{array}$ & $\begin{array}{l}-0.0065 \\
(0.0126)\end{array}$ \\
\hline Sample mean & 0.12 & 0.07 \\
\hline Number of observations & 12,540 & 7,326 \\
\hline
\end{tabular}

Notes: All OLS regressions also include the full set of mothers' year of birth dummies, federal state dummies, interactions of federal state dummies with a linear trend in mothers' year of birth, a dummy for female, dummies for children's age, and dummies for the survey year. Each coefficient is estimated in a separate regression. Standard errors are clustered at the federal state $\times$ mothers' birth year level and reported in parentheses. ${ }^{*} p<0.1,{ }^{* *} p<0.05, * * * p<0.01$.

Source: RDC (2017), German Micro Census 1989, 1995, 1999, 2003, 2005, 2009, own calculations. 


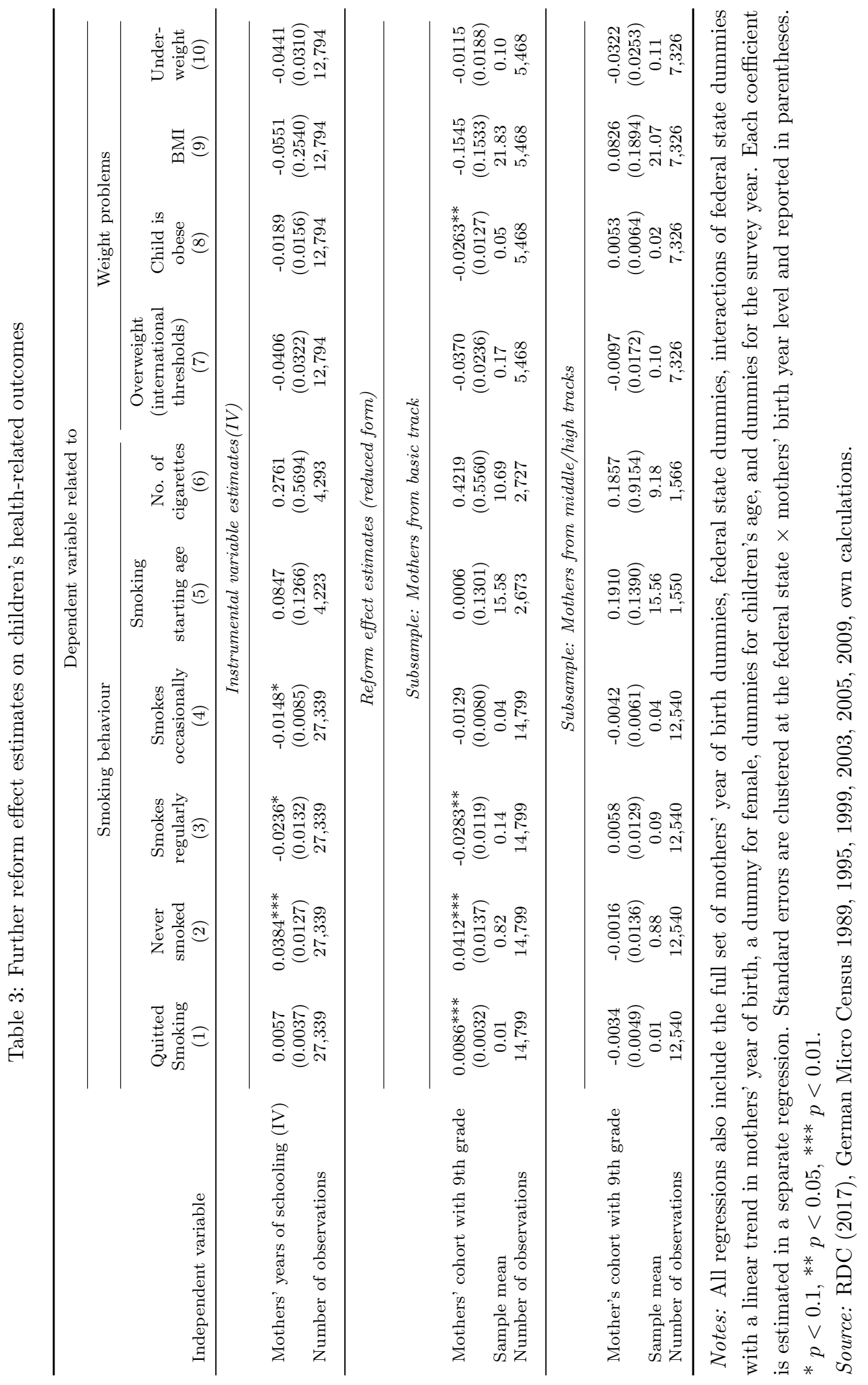


Table 4: Heterogeneity analysis of mothers' schooling effects

\begin{tabular}{|c|c|c|c|c|}
\hline \multirow[b]{3}{*}{ Independent variable } & \multicolumn{4}{|c|}{ Dependent variable: } \\
\hline & \multicolumn{2}{|c|}{ Currently smoking } & \multicolumn{2}{|c|}{ Overweight } \\
\hline & Coefficient & s.e. & Coefficient & s.e. \\
\hline & \multicolumn{4}{|c|}{ By gender } \\
\hline Cohort with 9 th grade $\cdot$ female & $-0.0259^{*}$ & $(0.0148)$ & $-0.0531^{* *}$ & $(0.0215)$ \\
\hline Cohort with 9 th grade $\cdot$ male & $-0.0554^{* * *}$ & $(0.0156)$ & $-0.0419^{*}$ & $(0.0215)$ \\
\hline \multirow[t]{2}{*}{ P-value for group difference } & 0.03 & & 0.55 & \\
\hline & \multicolumn{4}{|c|}{ By household income } \\
\hline Cohort with 9 th grade $\cdot$ below median & $-0.0473^{* * *}$ & $(0.0155)$ & $-0.0412^{*}$ & $(0.0227)$ \\
\hline Cohort with 9 th grade $\cdot$ above median & $-0.0316^{* *}$ & $(0.0142)$ & $-0.0575^{* *}$ & $(0.0234)$ \\
\hline \multirow[t]{2}{*}{$\mathrm{P}$-value for group difference } & 0.18 & & 0.51 & \\
\hline & \multicolumn{4}{|c|}{ By single mother status } \\
\hline Cohort with 9 th grade $\cdot$ single mother & $-0.0493^{* *}$ & $(0.0236)$ & $-0.0831^{* *}$ & $(0.0369)$ \\
\hline Cohort with 9 th grade $\cdot$ both parents & $-0.0386^{* * *}$ & $(0.0139)$ & $-0.0423^{* *}$ & $(0.0199)$ \\
\hline \multirow[t]{2}{*}{ P-value for group difference } & 0.63 & & 0.26 & \\
\hline & \multicolumn{4}{|c|}{ By mother's smoking behaviour } \\
\hline Cohort with 9 th grade $\cdot$ smoking & $-0.0343^{*}$ & $(0.0186)$ & -0.0327 & $(0.0271)$ \\
\hline Cohort with 9 th grade $\cdot$ non-smoking & $-0.0406^{* * *}$ & $(0.0138)$ & $-0.0483^{* *}$ & $(0.0206)$ \\
\hline \multirow[t]{2}{*}{ P-value for group difference } & 0.70 & & 0.53 & \\
\hline & \multicolumn{4}{|c|}{ By mother's overweight } \\
\hline Cohort with 9 th grade $\cdot$ overweight & $-0.0395^{* * *}$ & $(0.0143)$ & $-0.0590 * *$ & $(0.0234)$ \\
\hline Cohort with 9 th grade $\cdot$ not overweight & $-0.0496^{* *}$ & $(0.0217)$ & $-0.0453^{* *}$ & $(0.0214)$ \\
\hline P-value for group difference & 0.62 & & 0.60 & \\
\hline Number of observations & 14,799 & & 5,468 & \\
\hline
\end{tabular}

Notes: All OLS regressions are based on the sample of children with mothers from low tracks. The regressions also include the full set of mothers' year of birth dummies, federal state dummies, interactions of federal state dummies with a linear trend in mothers' year of birth, a dummy for female, dummies for children's age, dummies for the survey year, a quartic in mothers' age, and the interaction variable. Each coefficient is estimated in a separate regression. Standard errors are clustered at the federal state $\times$ mothers' birth year level and reported in parentheses. Mothers' smoking behaviour is missing for 29 observations. ${ }^{*} p<0.1,{ }^{*} p<0.05,{ }^{* * *} p<0.01$.

Source: RDC (2017), German Micro Census 1989, 1995, 1999, 2003, 2005, 2009, own calculations. 


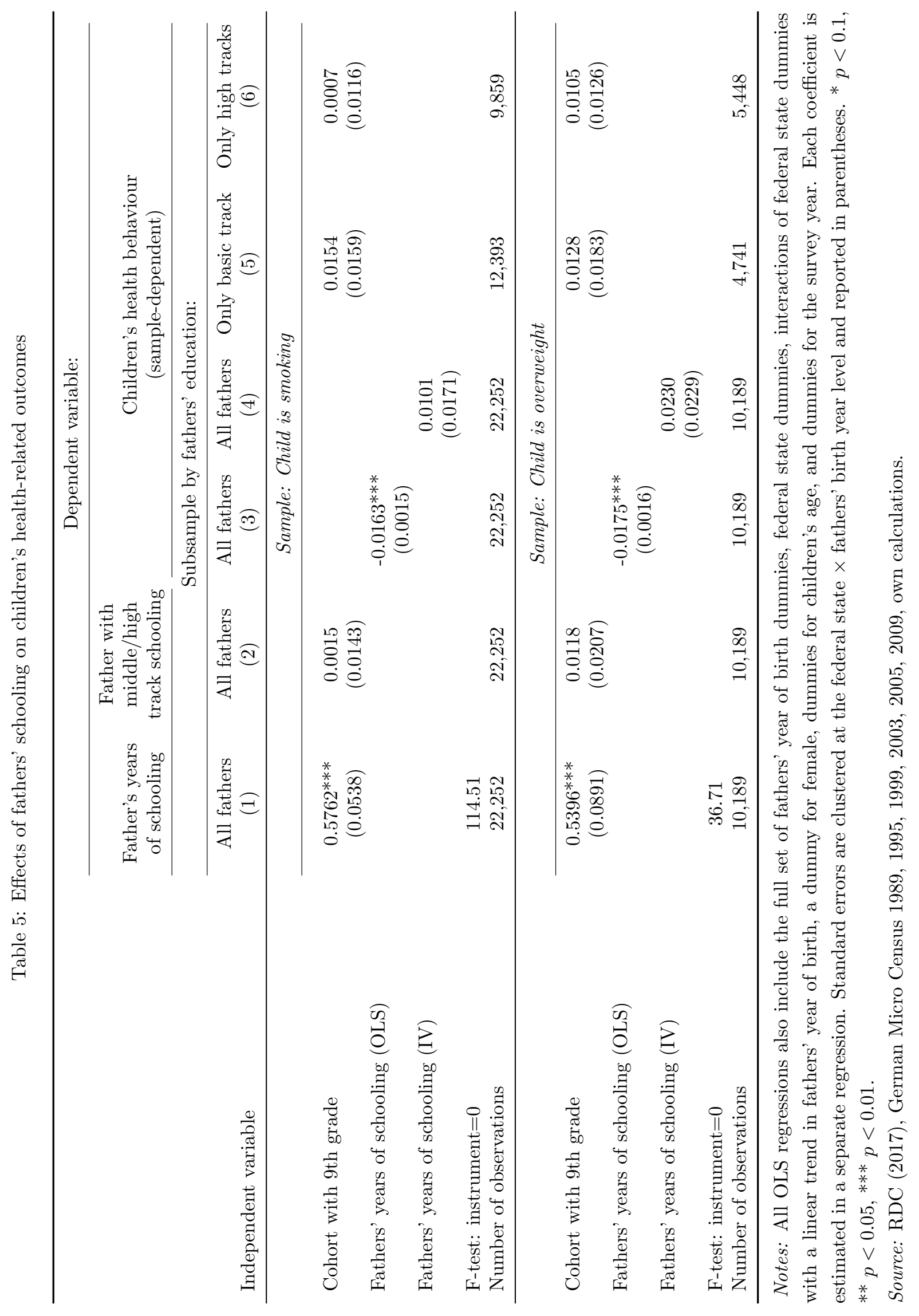


Table 6: Effects of parental schooling on children's health-related outcomes at age 30-50

\begin{tabular}{|c|c|c|c|c|c|c|c|}
\hline \multirow[b]{2}{*}{ Independent variable } & \multicolumn{7}{|c|}{ Dependent variable measured at age $30-50$ : } \\
\hline & $\begin{array}{c}\text { Currently } \\
\text { smoking } \\
\text { (1) }\end{array}$ & $\begin{array}{c}\text { Quitted } \\
\text { smoking } \\
(2)\end{array}$ & $\begin{array}{c}\text { Never } \\
\text { smoked } \\
(3)\end{array}$ & $\begin{array}{l}\text { BMI } \\
(4)\end{array}$ & $\begin{array}{c}\text { Overweight } \\
(\mathrm{BMI}>25) \\
(5)\end{array}$ & $\begin{array}{c}\text { Chronic } \\
\text { condition } \\
(6)\end{array}$ & $\begin{array}{c}\text { General } \\
\text { health } \\
\text { (z-score) } \\
(7)\end{array}$ \\
\hline & \multicolumn{7}{|c|}{ Panel A: Effects of mothers' schooling } \\
\hline & \multicolumn{7}{|c|}{ Sample: Mothers from basic track } \\
\hline Mother's cohort with 9th grade & $\begin{array}{c}-0.0905^{* *} \\
(0.0383)\end{array}$ & $\begin{array}{c}0.0436 \\
(0.0347)\end{array}$ & $\begin{array}{l}0.0802^{*} \\
(0.0442)\end{array}$ & $\begin{array}{c}-0.8893^{* *} \\
(0.3803)\end{array}$ & $\begin{array}{l}-0.0606^{*} \\
(0.0335)\end{array}$ & $\begin{array}{c}-0.0677^{* * *} \\
(0.0231)\end{array}$ & $\begin{array}{l}0.0960^{*} \\
(0.0528)\end{array}$ \\
\hline Sample mean & 0.35 & 0.19 & 0.39 & 25.92 & 0.52 & 0.31 & -0.05 \\
\hline Number of person-year obs. & 27,901 & 10,991 & 10,991 & 21,320 & 21,320 & 21,180 & 65,845 \\
\hline \multirow[t]{2}{*}{ Number of individuals } & 8,035 & 5,238 & 5,238 & 7,421 & 7,421 & 6,826 & 9,572 \\
\hline & \multicolumn{7}{|c|}{ Sample: Mothers from middle/high tracks } \\
\hline Mother's cohort with 9 th grade & $\begin{array}{c}0.0279 \\
(0.0361)\end{array}$ & $\begin{array}{l}-0.0285 \\
(0.0525)\end{array}$ & $\begin{array}{c}0.0046 \\
(0.0662)\end{array}$ & $\begin{array}{c}0.4826 \\
(0.4462)\end{array}$ & $\begin{array}{c}0.0199 \\
(0.0435)\end{array}$ & $\begin{array}{c}0.0214 \\
(0.0291)\end{array}$ & $\begin{array}{c}0.0197 \\
(0.0573)\end{array}$ \\
\hline Sample mean & 0.27 & 0.20 & 0.46 & 24.92 & 0.42 & 0.29 & 0.11 \\
\hline Number of person-year obs. & 9,014 & 3,024 & 3,024 & 7,553 & 7,553 & 8,624 & 21,992 \\
\hline \multirow[t]{3}{*}{ Number of individuals } & 3,136 & 1,675 & 1,675 & 2,997 & 2,997 & 2,841 & 3,766 \\
\hline & \multicolumn{7}{|c|}{ Panel B: Effects of fathers' schooling } \\
\hline & \multicolumn{7}{|c|}{ Sample: Fathers from basic track } \\
\hline Father's cohort with 9th grade & $\begin{array}{l}-0.0047 \\
(0.0410)\end{array}$ & $\begin{array}{c}0.0001 \\
(0.0504)\end{array}$ & $\begin{array}{c}0.0321 \\
(0.0564)\end{array}$ & $\begin{array}{c}0.0629 \\
(0.4265)\end{array}$ & $\begin{array}{c}0.0266 \\
(0.0381)\end{array}$ & $\begin{array}{c}0.0139 \\
(0.0280)\end{array}$ & $\begin{array}{l}-0.0273 \\
(0.0591)\end{array}$ \\
\hline Sample mean & 0.36 & 0.18 & 0.40 & 26.00 & 0.52 & 0.31 & -0.06 \\
\hline Number of person-year obs. & 22,709 & 8,704 & 8,704 & 17,603 & 17,603 & 17,592 & 52,757 \\
\hline \multirow[t]{2}{*}{ Number of individuals } & 6,650 & 4,211 & 4,211 & 6,175 & 6,175 & 5,733 & 7,777 \\
\hline & \multicolumn{7}{|c|}{ Sample: Fathers from middle/high tracks } \\
\hline Father's cohort with 9th grade & $\begin{array}{c}0.0265 \\
(0.0475)\end{array}$ & $\begin{array}{c}0.0273 \\
(0.0525)\end{array}$ & $\begin{array}{c}-0.0163 \\
(0.0822)\end{array}$ & $\begin{array}{c}0.1218 \\
(0.4705)\end{array}$ & $\begin{array}{l}-0.0519 \\
(0.0457)\end{array}$ & $\begin{array}{c}0.0183 \\
(0.0361)\end{array}$ & $\begin{array}{c}0.0573 \\
(0.0617)\end{array}$ \\
\hline Sample mean & 0.28 & 0.21 & 0.44 & 24.95 & 0.42 & 0.29 & 0.13 \\
\hline Number of person-year obs. & 8,824 & 2,942 & 2,942 & 7,448 & 7,448 & 8,495 & 20,925 \\
\hline Number of individuals & 3,059 & 1,643 & 1,643 & 2,933 & 2,933 & 2,794 & 3,575 \\
\hline
\end{tabular}

Notes: All OLS regressions also include the full set of mothers' year of birth dummies, federal state dummies, interactions of federal state dummies with a linear trend in mothers' year of birth, a dummy for female, dummies for children's age, and dummies for the survey year. Each coefficient is estimated in a separate regression. Standard errors are clustered at the federal state $\times$ mothers' birth year level and reported in parentheses. ${ }^{*} p<0.1,{ }^{* *} p<0.05,{ }^{* * *} p<0.01$.

Source: SOEP v32long, own calculations. 
Table 7: Effects of mothers' schooling on children's human capital

\begin{tabular}{lcccc}
\hline & \multicolumn{3}{c}{ Dependent variable: Child's school track } \\
\cline { 2 - 5 } Independent variable & $\begin{array}{c}\text { Middle/high } \\
(1)\end{array}$ & $\begin{array}{c}\text { Middle } \\
(2)\end{array}$ & $\begin{array}{c}\text { High } \\
(3)\end{array}$ & $\begin{array}{c}\text { Middle/high } \\
(4)\end{array}$ \\
\hline Mother's cohort with 9th grade & $0.0376^{* * *}$ & $0.0312^{*}$ & 0.0064 & \\
Mother's cohort with 9th grade $\cdot$ female & $(0.0144)$ & $(0.0163)$ & $(0.0163)$ & 0.0259 \\
& & & & $0.0166)$ \\
Mother's cohort with 9th grade · male & & & & $0.0483^{* * *}$ \\
Sample mean & & & & $0.0164)$ \\
Number of observations & 0.56 & 0.29 & 0.27 & 0.56 \\
& 16,081 & 16,081 & 16,081 & 16,081 \\
\hline
\end{tabular}

Notes: All analyses are based on children aged between 17 and 18 with mothers from the basic track. The OLS regressions include the treatment dummy, the full set of mothers' year of birth dummies, federal state dummies, interactions of federal state dummies with a linear trend in mothers' year of birth, a dummy for female, dummies for children's age, and dummies for the survey year. Standard errors are clustered at the federal state $\times$ mothers' birth year level and reported in parentheses. * $p<0.1,{ }^{* *} p<0.05,{ }^{* * *} p<0.01$.

Source: RDC (2017), German Micro Census 1989, 1995, 1999, 2003, 2005, 2009, own calculations. 
Table 8: Effects of mothers' schooling on family characteristics and parents' health-related outcomes

\begin{tabular}{|c|c|c|c|c|}
\hline \multirow[b]{2}{*}{ Dependent variable } & \multicolumn{4}{|c|}{ Sample: Mothers from basic track } \\
\hline & $\begin{array}{c}\text { Sample } \\
\text { mean } \\
(1)\end{array}$ & $\begin{array}{c}\text { Reduced } \\
\text { form effect } \\
\qquad(2)\end{array}$ & $\begin{array}{l}\text { s.e. } \\
(3)\end{array}$ & $\begin{array}{c}\text { Number of } \\
\text { observations } \\
(4)\end{array}$ \\
\hline & \multicolumn{4}{|c|}{ Panel A: Mothers' labour market outcomes } \\
\hline Mother works & 0.48 & 0.0158 & $(0.0107)$ & 70,477 \\
\hline \multirow[t]{2}{*}{ Mother's log hourly wage } & 1.49 & 0.0058 & $(0.0124)$ & 70,477 \\
\hline & \multicolumn{4}{|c|}{ Panel B: Assortative mating } \\
\hline Father's age in years & 43.96 & $0.1555^{*}$ & $(0.0828)$ & 62,811 \\
\hline Father's years of schooling & 8.99 & $0.2324 * * *$ & $(0.0346)$ & 62,811 \\
\hline Father's from middle/high tracks & 0.22 & 0.0081 & $(0.0095)$ & 62,811 \\
\hline Father works & 0.91 & -0.0039 & $(0.0075)$ & 62,811 \\
\hline \multirow[t]{2}{*}{ Father's log hourly wage } & 2.36 & 0.0112 & $(0.0156)$ & 62,811 \\
\hline & \multicolumn{4}{|c|}{ Panel $C:$ Family characteristics } \\
\hline Single mother & 0.13 & -0.0065 & $(0.0063)$ & 70,477 \\
\hline Mother is married & 0.88 & 0.0040 & $(0.0063)$ & 70,477 \\
\hline Number of children in $\mathrm{HH}$ & 2.14 & $-0.0467^{*}$ & $(0.0273)$ & 70,477 \\
\hline \multirow[t]{2}{*}{ Mother's age at child birth } & 29.93 & 0.0639 & $(0.0670)$ & 70,477 \\
\hline & \multicolumn{4}{|c|}{ Panel D: Parents'smoking behaviour } \\
\hline Mother smokes & 0.35 & 0.0061 & $(0.0139)$ & 36,462 \\
\hline Mother has never smoked & 0.49 & -0.0080 & $(0.0150)$ & 36,462 \\
\hline Father smokes & 0.40 & 0.0080 & $(0.0160)$ & 32,597 \\
\hline Father has never smoked & 0.35 & 0.0172 & $(0.0174)$ & 32,597 \\
\hline At least one parent smokes & 0.51 & 0.0084 & $(0.0172)$ & 38,117 \\
\hline \multirow[t]{2}{*}{ Parents have never smoked } & 0.28 & 0.0064 & $(0.0151)$ & 36,462 \\
\hline & \multicolumn{4}{|c|}{ Panel E: Parents' overweight } \\
\hline Mother's BMI & 25.08 & 0.1178 & $(0.3227)$ & 10,723 \\
\hline Mother is overweight & 0.43 & 0.0162 & $(0.0386)$ & 10,723 \\
\hline Father's BMI & 27.16 & -0.2069 & $(0.2362)$ & 9,280 \\
\hline Father is overweight & 0.70 & $-0.0773^{* * *}$ & $(0.0251)$ & 9,280 \\
\hline
\end{tabular}

Notes: The table reports the coefficient estimates of the treatment dummy "mothers' cohort with 9th grade in basic track" from OLS regressions further including the full set of mothers' year of birth dummies, federal state dummies, interactions of federal state dummies with a linear trend in mothers' year of birth, a dummy for female, dummies for children's age, and dummies for the survey year. All analyses are based on parents of children aged 18 and younger. Fathers' outcomes refer to reform effect estimates of maternal education on fathers' health behaviour (assortative mating and mothers' spill over effects). Each coefficient is estimated in a separate regression. Standard errors are clustered at the federal state $\times$ mothers' birth year level and reported in parentheses. ${ }^{*} p<0.1$, ** $p<0.05, * * * p<0.01$.

Source: RDC (2017), German Micro Census 1989, 1995, 1999, 2003, 2005, 2009, own calculations. 
Table 9: Placebo reforms and placebo outcome

\begin{tabular}{|c|c|c|c|c|c|}
\hline \multirow[b]{3}{*}{ Independent variable } & \multicolumn{5}{|c|}{ Panel A: Placebo reforms } \\
\hline & \multirow{2}{*}{$\begin{array}{l}\text { Actual } \\
\text { reform } \\
\quad(1)\end{array}$} & \multicolumn{4}{|c|}{ Placebo reforms in } \\
\hline & & $\begin{array}{l}\mathrm{t}-2 \\
(2)\end{array}$ & $\begin{array}{l}\text { t-3 } \\
(3)\end{array}$ & $\begin{array}{l}\mathrm{t}-4 \\
(4)\end{array}$ & $\begin{array}{l}\mathrm{t}-5 \\
(5)\end{array}$ \\
\hline & \multicolumn{5}{|c|}{ Dependent variable: Currently smoking } \\
\hline Mother's cohort with 9th grade & $\begin{array}{c}-0.0412^{* * *} \\
(0.014)\end{array}$ & $\begin{array}{l}0.0308 \\
(0.021)\end{array}$ & $\begin{array}{l}-0.0181 \\
(0.022)\end{array}$ & $\begin{array}{r}-0.0031 \\
(0.023)\end{array}$ & $\begin{array}{l}0.0196 \\
(0.020)\end{array}$ \\
\hline \multirow[t]{2}{*}{ Number of observations } & 14,799 & 7,087 & 7,087 & 7,087 & 7,087 \\
\hline & \multicolumn{5}{|c|}{ Dependent variable: Overweight } \\
\hline Mother's cohort with 9th grade & $\begin{array}{c}-0.0474^{* *} \\
(0.019)\end{array}$ & $\begin{array}{l}0.0306 \\
(0.058)\end{array}$ & $\begin{array}{r}-0.0555 \\
(0.039)\end{array}$ & $\begin{array}{r}-0.0029 \\
(0.064)\end{array}$ & $\begin{array}{l}0.0315 \\
(0.058)\end{array}$ \\
\hline \multirow[t]{3}{*}{ Number of observations } & 5,468 & 1,166 & 1,166 & 1,166 & 1,166 \\
\hline & \multicolumn{5}{|c|}{ Panel B: Placebo outcome } \\
\hline & \multicolumn{5}{|c|}{$\begin{array}{l}\text { Dependent variable: Body height in cm (age 30-50) } \\
\text { SOEP sample, children with mothers from basic track }\end{array}$} \\
\hline Mother's cohort with 9th grade & $\begin{array}{l}-0.0629 \\
(0.5393)\end{array}$ & & & & \\
\hline Sample mean & 172.88 & & & & \\
\hline Number of person-year observations & 21,320 & & & & \\
\hline
\end{tabular}

Notes: All OLS regressions also include the full set of mothers' year of birth dummies, federal state dummies, interactions of federal state dummies with a linear trend in mothers' year of birth, a dummy for female, dummies for children's age, dummies for the survey year and a quartic in mothers' age. Each coefficient is estimated in a separate regression. Standard errors are clustered at the federal state $\times$ mothers' birth year level and reported in parentheses. * $p<0.1,{ }^{* *} p<0.05,{ }^{* * *} p<0.01$.

Source: RDC (2017), German Micro Census 1989, 1995, 1999, 2003, 2005, 2009 and SOEP v32long, own calculations. 


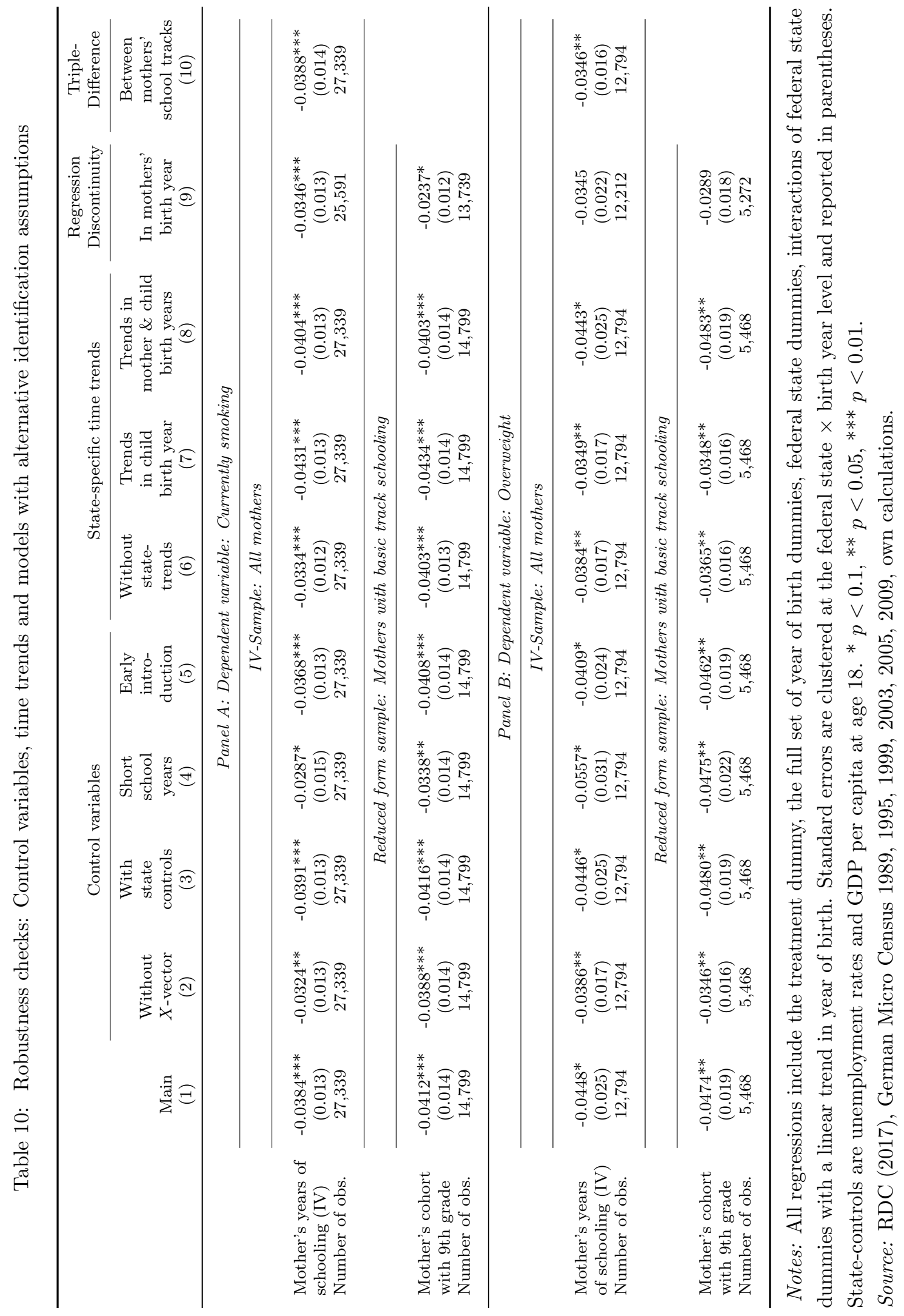




\section{Appendix}

Figure A.1: Share of children living with at least one parent by children's age

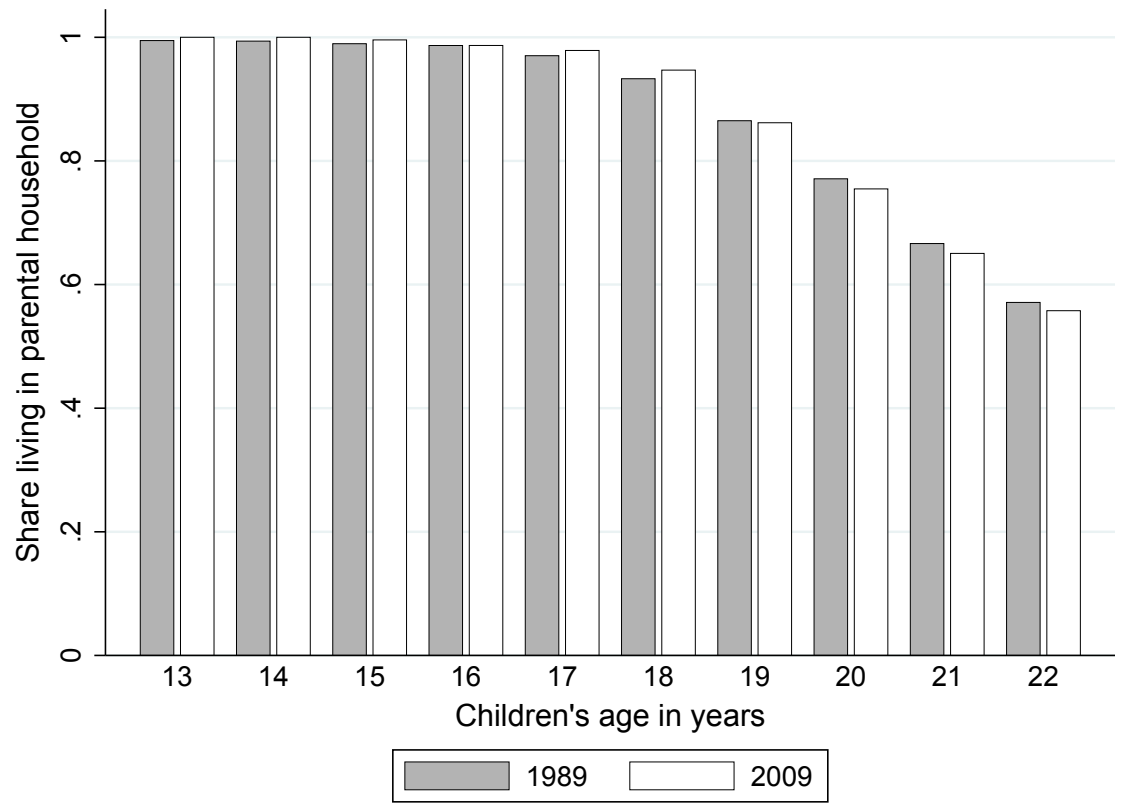

Notes: The figure plots the share of children in private households living with at least one parent. Children in the main samples are between 15 and 18 years old.

Source: RDC (2017), German Micro Census 1989, 2009, own illustration. 
Figure A.2: Residuals from the difference-in-differences regression models of children's health-related outcomes on mothers' compulsory schooling exposure

Panel A: Outcome: Child is smoking (age 15-18)
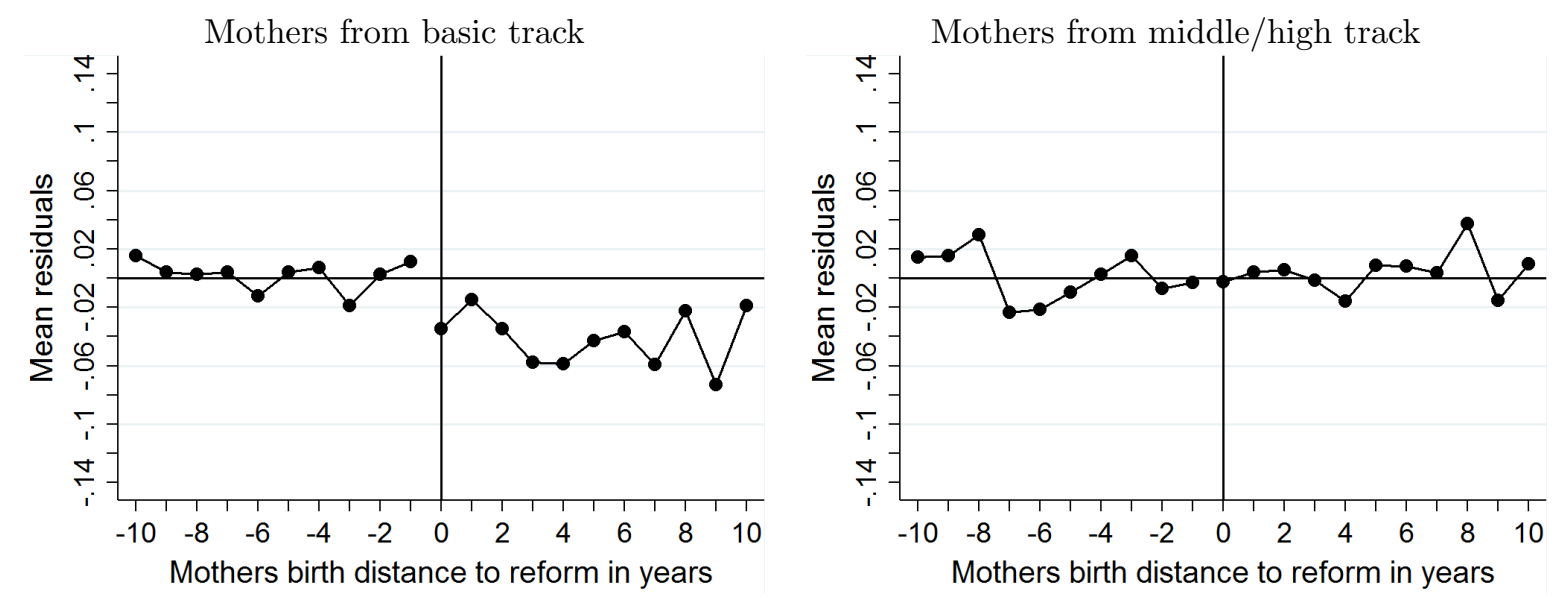

Panel B: Outcome: Child is overweight (age 15-18)
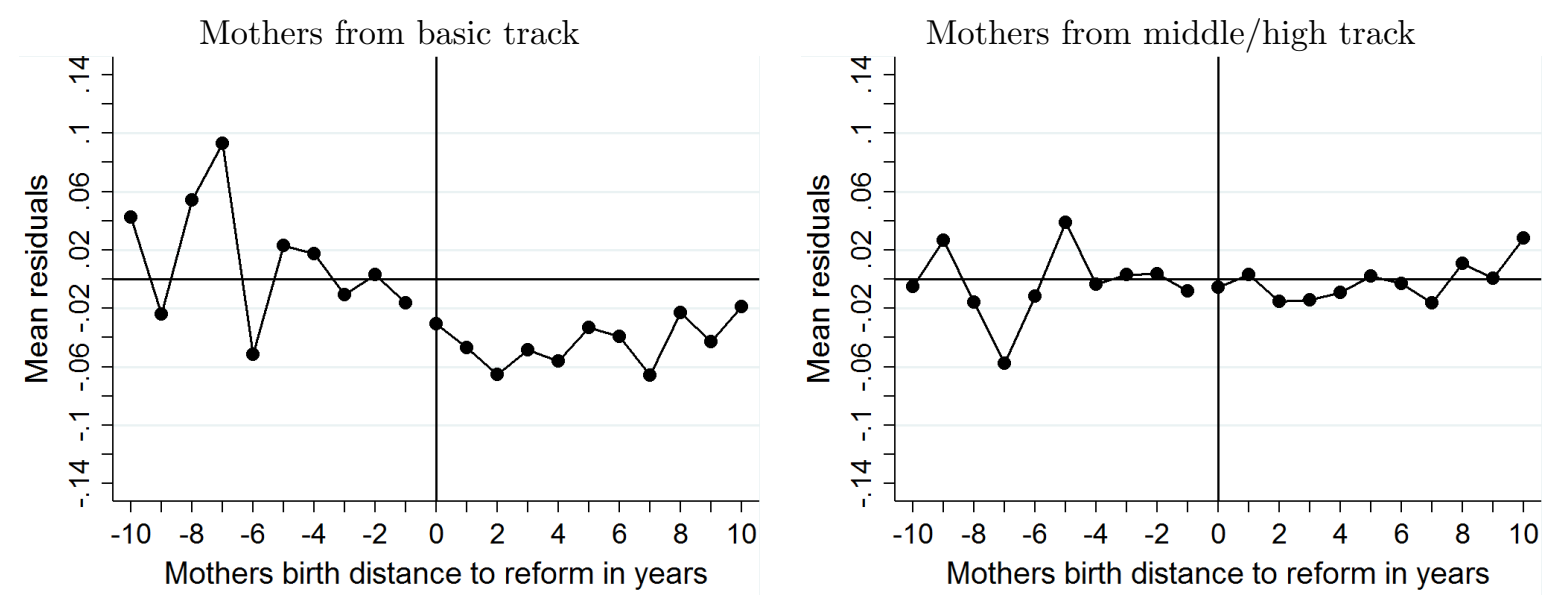

Notes: The graphs plot residuals from the main difference-in-differences regression models employed to estimate the impact of mothers' exposure to the compulsory schooling reform on children's smoking behaviour and overweight (treatment dummy added back in) for children of mothers from basic track schools (affected group) and middle/high track schools (unaffected group).

Source: RDC (2017), German Micro Census 1989, 1995, 1999, 2003, 2005, 2009, own illustration. 
Figure A.3: Distributions of mothers' year of birth and mothers' age at birth

Panel A: Distribution of mothers' year of birth
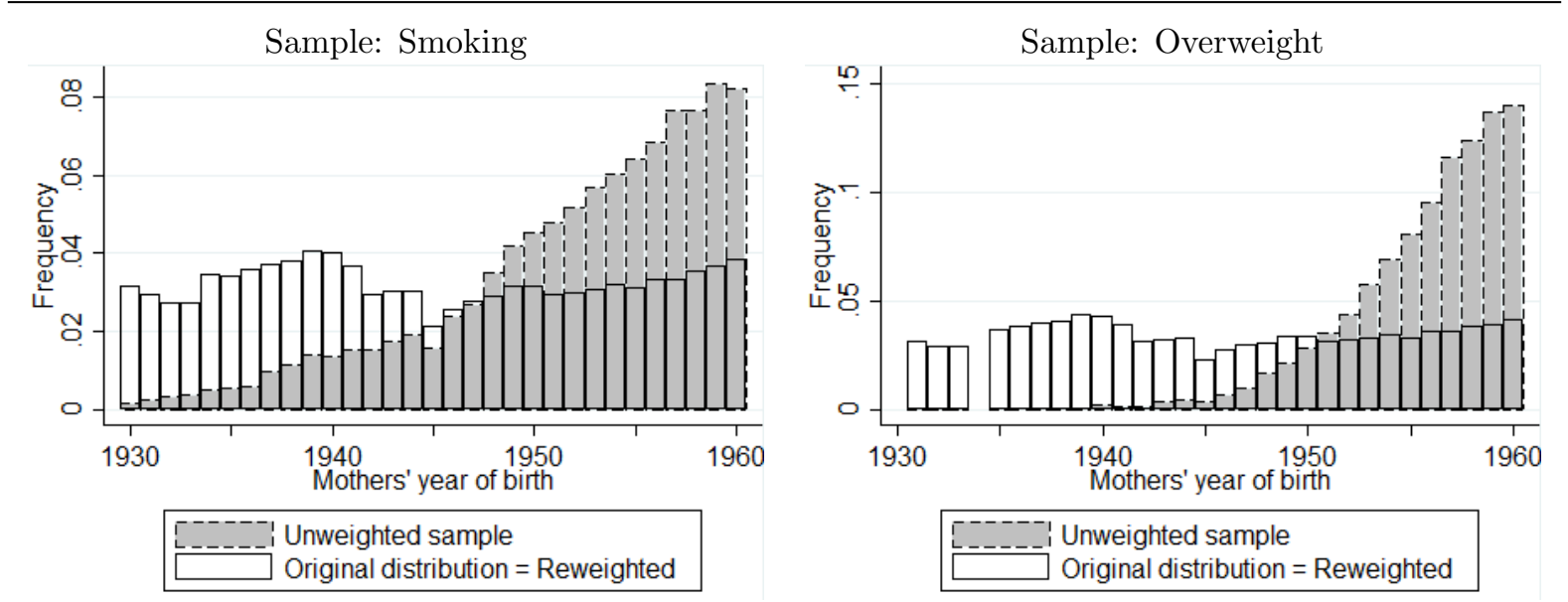

Panel B: Distribution of mothers' age at birth
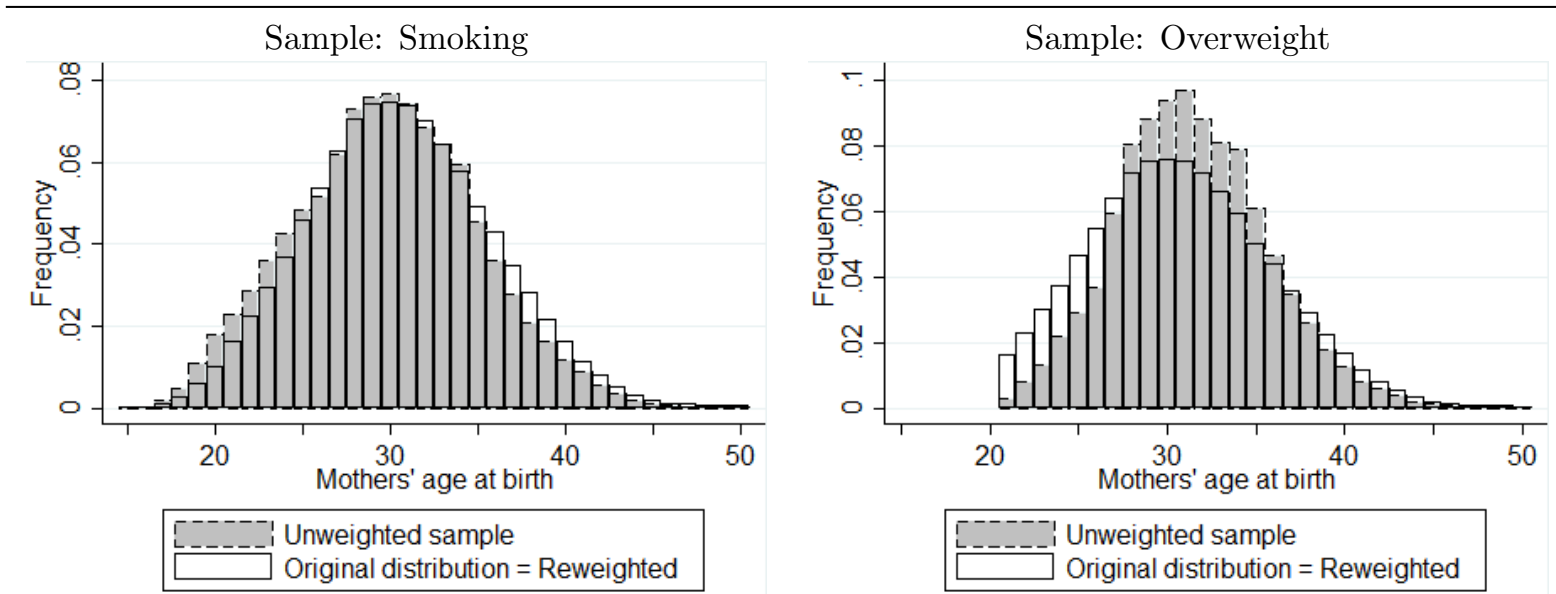

Notes: The histograms plot the distributions of mothers' year of birth and mothers' age at childbirth in the population and in the two main samples. The population distributions are used to construct inverse probability weights that are employed in weighted regressions reported in Table B.10.

Source: RDC (2017), German Micro Census 1989, 1995, 1999, 2003, 2005, 2009, own illustration. 
Table B.1: Introduction of 9th grade in basic track of secondary school.

\begin{tabular}{lcc}
\hline State & $\begin{array}{c}\text { First year when } \\
\text { all students are } \\
\text { (Bundesland) }\end{array}$ & $\begin{array}{c}\text { Birth cohorts } \\
\text { with 9 years } \\
\text { of school }\end{array}$ \\
\hline Hamburg & 1949 & 1934 \\
Schleswig-Holstein & 1956 years & 1941 \\
Bremen & 1958 & 1943 \\
Niedersachsen & 1962 & 1947 \\
Saarland & 1964 & 1949 \\
Nordrhein-Westfalen & 1967 & 1953 \\
Hessen & 1967 & 1953 \\
Rheinland-Pfalz & 1967 & 1953 \\
Baden-Württemberg & 1967 & 1953 \\
Bayern & 1969 & 1955 \\
\hline
\end{tabular}

Source: Pischke and von Wachter (2005).

Table B.2: Share of children aged 15-18 living with at least one parent

\begin{tabular}{ccccccc}
\hline & \multicolumn{7}{c}{ Year } \\
\cline { 2 - 7 } All years & 1989 & 1995 & 1999 & 2003 & 2005 & 2009 \\
\hline 96.50 & 96.75 & 96.21 & 95.78 & 95.89 & 96.72 & 97.63 \\
$(18.39)$ & $(17.74)$ & $(19.09)$ & $(20.11)$ & $(19.86)$ & $(17.81)$ & $(15.20)$ \\
\hline
\end{tabular}

Notes: The table reports descriptive statistics on the share of individuals in private households aged 15-18 living with at least one parent. Standard deviations are reported in parentheses.

Source: RDC (2017), German Micro Census 1989, 1995, 1999, 2003, 2005, 2009, own calculations. 
Table B.3: Statistical relationship for missing information on child outcomes

\begin{tabular}{|c|c|c|}
\hline \multirow[b]{2}{*}{ Independent variable } & \multicolumn{2}{|c|}{$\begin{array}{l}\text { Dependent variable (child outcome): } \\
\text { Missing information for }\end{array}$} \\
\hline & $\begin{array}{c}\text { Currently } \\
\text { smoking } \\
\text { (1) }\end{array}$ & $\begin{array}{l}\text { Overweight } \\
(2)\end{array}$ \\
\hline & \multicolumn{2}{|c|}{ Panel A: Multivariate regressions } \\
\hline Child age & $\begin{array}{c}-0.0056^{* * *} \\
(0.0019)\end{array}$ & $\begin{array}{c}0.0000 \\
(0.0030)\end{array}$ \\
\hline Female & $\begin{array}{l}-0.0045 \\
(0.0044)\end{array}$ & $\begin{array}{c}0.0117 \\
(0.0072)\end{array}$ \\
\hline Mothers' years of schooling & $\begin{array}{c}0.0043^{* *} \\
(0.0020)\end{array}$ & $\begin{array}{c}0.0077^{* * *} \\
(0.0029)\end{array}$ \\
\hline Fathers' years of schooling & $\begin{array}{c}0.0058^{* * *} \\
(0.0016)\end{array}$ & $\begin{array}{c}0.0057^{* *} \\
(0.0024)\end{array}$ \\
\hline Household net income (in 1000 EUR) & $\begin{array}{l}-0.0021 \\
(0.0017)\end{array}$ & $\begin{array}{c}-0.0058^{* *} \\
(0.0026)\end{array}$ \\
\hline Number of observations & 31,353 & 18,268 \\
\hline
\end{tabular}

\begin{tabular}{lcc}
\hline & Panel B: Instrumental variable estimations \\
\cline { 2 - 3 } & \multicolumn{2}{c}{ Sample: Mothers } \\
\cline { 2 - 3 } Mother's years of schooling (IV) & 0.0022 & -0.0191 \\
& $(0.0157)$ & $(0.0344)$ \\
Sample mean & 0.16 & 0.30 \\
Number of observations & 31,353 & 18,268 \\
& & Sample: Fathers \\
Father's years of schooling (IV) & 0.0215 & 0.0253 \\
Sample mean & $(0.0231)$ & $(0.0371)$ \\
Number of observations & 0.16 & 0.30 \\
& 25,417 & 14,525 \\
\hline
\end{tabular}

Notes: OLS regressions in Panel A also include the full set of mothers' year of birth dummies, federal state dummies, interactions of federal state dummies with a linear trend in mothers' year of birth and dummies for the survey year. The regressions include dummy variables for missing information for socioeconomic characteristics. In Panel B, IV-estimations are based on the main estimation model outlined in Section B. Each coefficient is estimated in a separate regression. Standard errors are clustered at the federal state $\times$ mothers' birth year level and reported in parentheses. $* p<0.1$, ** $p<0.05, * * * p<0.01$.

Source: RDC (2017), German Micro Census 1989, 1995, 1999, 2003, 2005, 2009, own calculations. 
Table B.4: Descriptive statistics for the main samples

\begin{tabular}{|c|c|c|c|c|}
\hline & \multicolumn{4}{|c|}{ Sample by child outcome (age $15-18$ ) } \\
\hline & \multicolumn{2}{|c|}{ Smoking $^{1}$} & \multicolumn{2}{|c|}{ Overweight $^{2}$} \\
\hline & Sample mean & s.d. & Sample mean & s.d. \\
\hline & \multicolumn{4}{|c|}{ Child characteristics } \\
\hline Currently smoking (D) & 0.16 & $(0.36)$ & & \\
\hline Overweight (D) & & & 0.10 & $(0.30)$ \\
\hline Female (D) & 0.49 & $(0.50)$ & 0.48 & $(0.50)$ \\
\hline \multirow[t]{2}{*}{ Age in years } & 16.58 & $(1.11)$ & 16.62 & $(1.11)$ \\
\hline & \multicolumn{4}{|c|}{ Mother characteristics } \\
\hline Years of schooling & 9.69 & $(1.62)$ & 10.15 & $(1.61)$ \\
\hline Married (D) & 0.87 & $(0.33)$ & 0.86 & $(0.34)$ \\
\hline Working (D) & 0.66 & $(0.47)$ & 0.73 & $(0.44)$ \\
\hline Work hours/week (if working) & 26.94 & $(14.15)$ & 25.14 & $(13.16)$ \\
\hline Log hourly wage in EUR & 2.23 & $(0.58)$ & 2.30 & $(0.59)$ \\
\hline Age at birth in years & 29.82 & $(5.24)$ & 31.44 & $(4.31)$ \\
\hline Number of children in household & 2.07 & $(0.96)$ & 2.01 & $(0.91)$ \\
\hline Currently smoking (D) & 0.27 & $(0.44)$ & 0.27 & $(0.44)$ \\
\hline BMI & 24.33 & $(4.20)$ & 24.36 & $(4.20)$ \\
\hline \multirow[t]{2}{*}{$\mathrm{BMI}>25(\mathrm{D})$} & 0.35 & $(0.48)$ & 0.35 & $(0.48)$ \\
\hline & \multicolumn{4}{|c|}{ Partner characteristics } \\
\hline Years of schooling & 9.81 & $(1.87)$ & 10.29 & $(1.89)$ \\
\hline Working (D) & 0.91 & $(0.28)$ & 0.91 & $(0.29)$ \\
\hline Log hourly wage in EUR & 2.65 & $(0.47)$ & 2.73 & $(0.49)$ \\
\hline Currently smoking (D) & 0.31 & $(0.46)$ & 0.28 & $(0.45)$ \\
\hline BMI & 26.57 & $(3.66)$ & 26.57 & $(3.63)$ \\
\hline \multirow[t]{2}{*}{$\mathrm{BMI}>25(\mathrm{D})$} & 0.64 & $(0.48)$ & 0.64 & $(0.48)$ \\
\hline & \multicolumn{4}{|c|}{ Household characteristics } \\
\hline Household size & 4.00 & $(1.09)$ & 3.91 & $(1.05)$ \\
\hline Household net income in EUR & 3039.29 & $(1849.74)$ & 3499.39 & $(2099.31)$ \\
\hline Both parents in household & 0.86 & $(0.35)$ & 0.84 & $(0.36)$ \\
\hline Number of observations & 27,339 & & 12,794 & \\
\hline
\end{tabular}

Notes: The table provides descriptive statistics for the different samples depending on the child outcomes. Standard deviations are reported in parentheses.

Source: RDC (2017), ${ }^{1}$ based on German Micro Census 1989, 1995, 1999, 2003, 2005, 2009, 2 based on German Micro Census 1999, 2003, 2005, 2009. 
Table B.5: Robustness check: Clustering of standard errors

\begin{tabular}{|c|c|c|c|}
\hline \multirow[b]{2}{*}{ Independent variable } & \multirow[b]{2}{*}{$\begin{array}{c}\text { Coefficient } \\
\text { estimate } \\
\text { (1) }\end{array}$} & \multicolumn{2}{|c|}{$p$-value for clustering at } \\
\hline & & $\begin{array}{l}\text { Federal state - } \\
\text { mothers' } \\
\text { birth year level } \\
(2)\end{array}$ & $\begin{array}{c}\text { Federal } \\
\text { state } \\
\text { level } \\
(3)\end{array}$ \\
\hline \multirow{3}{*}{ Mother's cohort with 9 th grade } & \multicolumn{3}{|c|}{ Dependent variable: Child is smoking } \\
\hline & -0.0412 & {$[0.0029]^{* * *}$} & {$[0.0120]^{* *}$} \\
\hline & \multicolumn{3}{|c|}{ Dependent variable: Child is overweight } \\
\hline Mother's cohort with 9 th grade & -0.0474 & {$[0.0150]^{* *}$} & {$[0.0841]^{*}$} \\
\hline
\end{tabular}

Notes: Column (1) reports OLS coefficient estimates of the main specification in the sample of children with mothers from basic track schools. Column (2) reports $p$-values based on robust standard errors clustered at the federal state $\times$ mothers' birth year level (303 clusters for smoking, 202 clusters for overweight). Column (3) reports $p$-values based on clustering at the federal state level using wild cluster bootstrap procedures to account for the small number of clusters (10 clusters, 999 replications, Mammen weights, testing under H0, for details see Cameron et al., 2008). ${ }^{*} p<0.1,{ }^{* *} p<0.05$, *** $p<0.01$.

Source: RDC (2017), German Micro Census 1989, 1995, 1999, 2003, 2005, 2009, own calculations.

Table B.6: Comparing first-stage coefficients on mothers' schooling of imputed and observed information

\begin{tabular}{|c|c|c|c|c|c|c|}
\hline \multirow[b]{4}{*}{ Independent variable } & \multicolumn{6}{|c|}{ Sample } \\
\hline & \multicolumn{2}{|c|}{ Smoking } & \multicolumn{2}{|c|}{ Overweight } & \multicolumn{2}{|c|}{ All } \\
\hline & \multicolumn{6}{|c|}{ Dependent variable: Mother's years of education: } \\
\hline & $\begin{array}{l}\text { Imputed } \\
(1)\end{array}$ & $\begin{array}{c}\text { Observed } \\
(2)\end{array}$ & $\begin{array}{l}\text { Imputed } \\
(3)\end{array}$ & $\begin{array}{c}\text { Observed } \\
(4)\end{array}$ & Imputed & $\begin{array}{c}\text { Observed } \\
(6)\end{array}$ \\
\hline Mother's cohort with 9th grade & $\begin{array}{c}0.6454^{* * * *} \\
(0.0424)\end{array}$ & $\begin{array}{l}0.8044^{*} \\
(0.4208)\end{array}$ & $\begin{array}{c}0.4833^{* * * *} \\
(0.1051)\end{array}$ & $\begin{array}{c}0.4304 \\
(0.4444)\end{array}$ & $\begin{array}{c}0.6485 * * * \\
(0.0297)\end{array}$ & $\begin{array}{l}0.7114^{*} \\
(0.4004)\end{array}$ \\
\hline Number of observations & 27,339 & 7,736 & 12,794 & 6,700 & 55,217 & 9,074 \\
\hline
\end{tabular}

Notes: The table reports reduced form estimates of mothers' years of education on an indicator of a 9 th grade in the basic track. "Imputed" years of education are assigned based on mothers' school degree and the typical length of schooling in the federal state. "Observed" years of education are calculated from information on the year in which the highest vocational degree was completed. This information is only available for a subsample of $90 \%$ of individuals from 2005 onward. ${ }^{*} p<0.1,{ }^{* *} p<0.05,{ }^{* * *} p<0.01$.

Source: RDC (2017), German Micro Census 1989, 1995, 1999, 2003, 2005, 2009, own calculations. 
Table B.7: IV-weights

\begin{tabular}{lcc}
\hline & \multicolumn{2}{c}{ Sample } \\
\cline { 2 - 3 } Years of & Child is smoking & Child is overweight \\
schooling margins & $(1)$ & 0.988 \\
\hline 8 to 9 years & 0.961 & 0.001 \\
9 to 10 years & 0.004 & 0.010 \\
10 to 12 years & 0.018 & 0.000 \\
12 to 13 years & 0.017 & \\
\hline
\end{tabular}

Notes: The table reports weights that the IV estimator assigns to the marginal effects of maternal education across the years of schooling distribution. The weights are reported for the two main samples employed in the analyses. The weights were obtained based on the formulas provided in Løken et al. (2012). Source: RDC (2017), German Micro Census 1989, 1995, 1999, 2003, 2005, 2009, own calculations.

Table B.8: Only for certain age groups

\begin{tabular}{|c|c|c|c|c|}
\hline \multirow[b]{3}{*}{ Independent variable } & \multicolumn{4}{|c|}{ Dependent variable (child outcome): } \\
\hline & \multicolumn{2}{|c|}{ Smoking behaviour } & \multicolumn{2}{|c|}{ Overweight } \\
\hline & $\begin{array}{l}\text { Without state } \\
\text { time trends } \\
\text { (1) }\end{array}$ & $\begin{array}{l}\text { With state } \\
\text { time trends } \\
\quad(2)\end{array}$ & $\begin{array}{l}\text { Without state } \\
\text { time trends } \\
\text { (3) }\end{array}$ & $\begin{array}{l}\text { With state } \\
\text { time trends } \\
\text { (4) }\end{array}$ \\
\hline & \multicolumn{4}{|c|}{$\begin{array}{l}\text { Reduced form estimates for } \\
\text { children with mothers from the basic track }\end{array}$} \\
\hline & \multicolumn{4}{|c|}{ Sample: Only children aged 15-16 years } \\
\hline Mother's cohort with 9th grade & $\begin{array}{c}-0.0378^{* *} \\
(0.0146)\end{array}$ & $\begin{array}{c}-0.0388^{* * *} \\
(0.0149)\end{array}$ & $\begin{array}{c}-0.0484^{*} \\
(0.0261)\end{array}$ & $\begin{array}{c}-0.0384 \\
(0.0283)\end{array}$ \\
\hline \multirow[t]{2}{*}{ Number of observations } & 6,256 & 6,256 & 2,416 & 2,416 \\
\hline & \multicolumn{4}{|c|}{ Sample: Only children aged 17-18 years } \\
\hline Mother's cohort with 9th grade & $\begin{array}{c}-0.0468^{* *} \\
(0.0202)\end{array}$ & $\begin{array}{c}-0.0509^{* *} \\
(0.0204)\end{array}$ & $\begin{array}{c}-0.0314 \\
(0.0222)\end{array}$ & $\begin{array}{c}-0.0522^{* *} \\
(0.0262)\end{array}$ \\
\hline Number of observations & 7,774 & 7,774 & 3,052 & 3,052 \\
\hline
\end{tabular}

Notes: All OLS regressions also include the full set of mothers' year of birth dummies, federal state dummies, interactions of federal state dummies with a linear trend in mothers' year of birth, a dummy for female, dummies for children's age, dummies for the survey year and a quartic in mothers' age. Each coefficient is estimated in a separate regression. Standard errors are clustered at the federal state $\times$ mothers' birth year level and reported in parentheses. ${ }^{*} p<0.1,{ }^{* *} p<0.05$, *** $p<0.01$.

Source: RDC (2017), German Micro Census 1989, 1995, 1999, 2003, 2005, 2009, own calculations. 


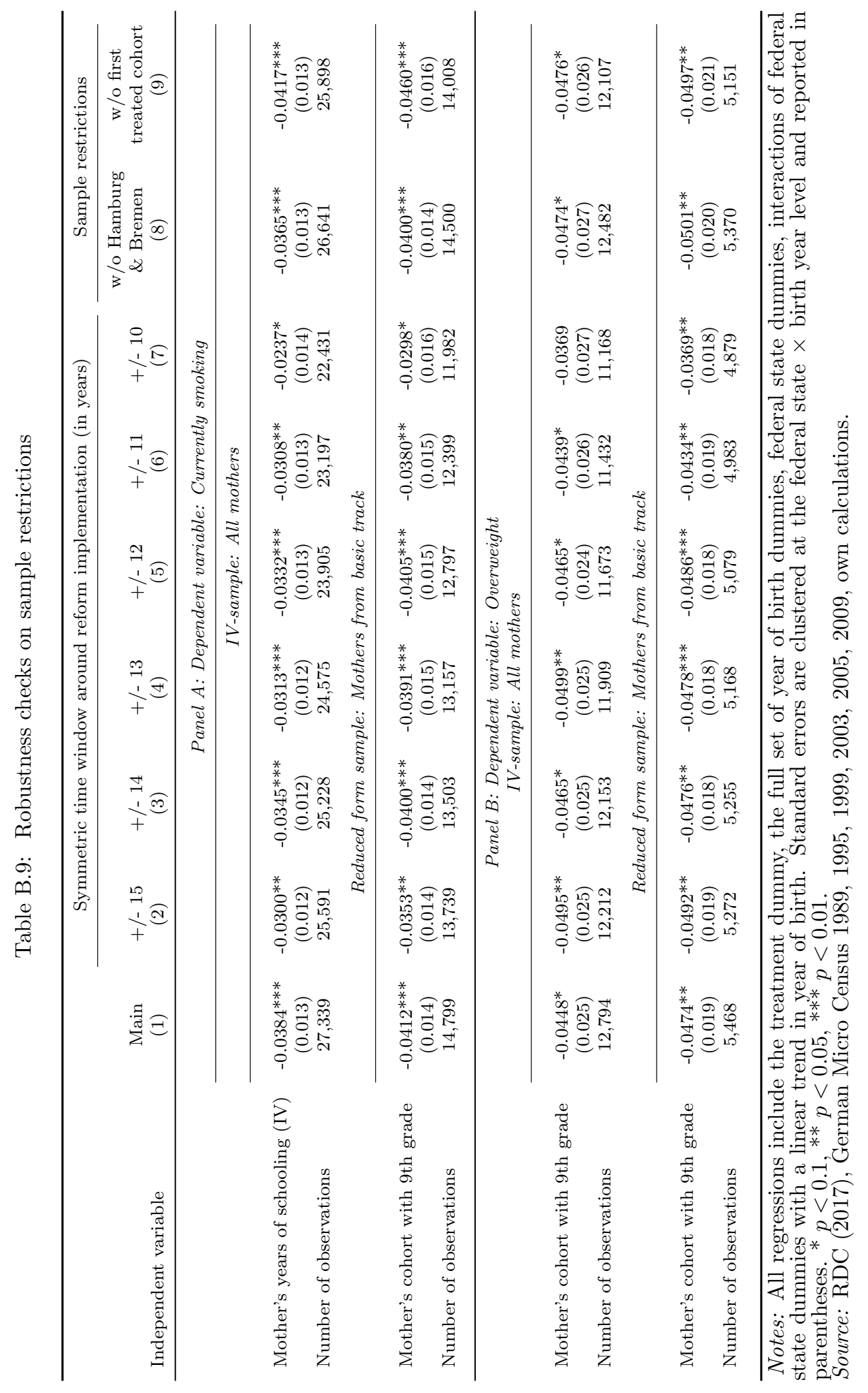


Table B.10: Weighted regression models

\begin{tabular}{|c|c|c|c|}
\hline \multirow[b]{2}{*}{ Independent variable } & \multirow[b]{2}{*}{$\begin{array}{l}\text { Unweighted } \\
\text { (main) } \\
(1)\end{array}$} & \multicolumn{2}{|c|}{$\begin{array}{l}\text { Regressions reweighted to } \\
\text { match distribution of }\end{array}$} \\
\hline & & $\begin{array}{c}\text { Female births } \\
\text { 1930-1960 } \\
(2)\end{array}$ & $\begin{array}{c}\text { Mothers' age } \\
\text { at birth } \\
(3)\end{array}$ \\
\hline & \multicolumn{3}{|c|}{ Panel A: Dependent variable: Currently smoking } \\
\hline & \multicolumn{3}{|c|}{ IV sample: All mothers } \\
\hline Mother's years of schooling (IV) & $\begin{array}{c}-0.0384^{* * *} \\
(0.013)\end{array}$ & $\begin{array}{c}-0.0352^{*} \\
(0.019)\end{array}$ & $\begin{array}{c}-0.0414^{* * *} \\
(0.013)\end{array}$ \\
\hline \multirow[t]{2}{*}{ Number of observations } & 27,339 & 27,339 & 27,339 \\
\hline & \multicolumn{3}{|c|}{ Reduced form sample: Mothers from basic track } \\
\hline Mother's cohort with 9th grade & $\begin{array}{c}-0.0412^{* * *} \\
(0.014)\end{array}$ & $\begin{array}{c}-0.0324^{*} \\
(0.018)\end{array}$ & $\begin{array}{c}-0.0447^{* * *} \\
(0.014)\end{array}$ \\
\hline \multirow[t]{2}{*}{ Number of observations } & 14,799 & 14,799 & 14,799 \\
\hline & \multicolumn{3}{|c|}{ Reduced form sample: Mothers from middle/high tracks } \\
\hline Mother's cohort with 9 th grade & $\begin{array}{l}0.0016 \\
(0.014)\end{array}$ & $\begin{array}{c}-0.0005 \\
(0.014)\end{array}$ & $\begin{array}{l}0.0005 \\
(0.014)\end{array}$ \\
\hline \multirow[t]{3}{*}{ Number of observations } & 12,540 & 12,540 & 12,540 \\
\hline & \multicolumn{3}{|c|}{ Dep. variable: Overweight } \\
\hline & \multicolumn{3}{|c|}{ IV sample: All mothers } \\
\hline Mother's cohort with 9th grade & $\begin{array}{c}-0.0448^{*} \\
(0.025)\end{array}$ & $\begin{array}{r}-0.0554 \\
(0.047)\end{array}$ & $\begin{array}{c}-0.0503^{*} \\
(0.026)\end{array}$ \\
\hline \multirow[t]{2}{*}{ Number of observations } & 12,794 & 12,752 & 12,794 \\
\hline & \multicolumn{3}{|c|}{ Reduced form sample: Mothers from basic track } \\
\hline Mother's cohort with 9 th grade & $\begin{array}{c}-0.0474^{* *} \\
(0.019)\end{array}$ & $\begin{array}{c}-0.0462 \\
(0.029)\end{array}$ & $\begin{array}{c}-0.0598 * * * \\
(0.021)\end{array}$ \\
\hline \multirow[t]{2}{*}{ Number of observations } & 5,468 & 5,442 & 5,468 \\
\hline & \multicolumn{3}{|c|}{ Reduced form sample: Mothers from middle/high tracks } \\
\hline Mother's cohort with 9 th grade & $\begin{array}{l}-0.0065 \\
(0.013)\end{array}$ & $\begin{array}{r}-0.0071 \\
(0.017)\end{array}$ & $\begin{array}{r}-0.0051 \\
(0.012)\end{array}$ \\
\hline Number of observations & 7,326 & 7,310 & 7,326 \\
\hline
\end{tabular}

Notes: The table reports IV and reduced form estimates from unweighted and weighted regressions. Weighted regressions reweight the observations to match the birth frequencies based on mothers' birth year (information based on Micro Census 1989 for all females born between 1930 $\&$ 1960) and based on mothers' age at birth (based on the full sample of children aged 0-18 living with their parents, irrespective of provided child outcome information). ${ }^{*} p<0.1,{ }^{* *} p<0.05$, $* * * p<0.01$.

Source: RDC (2017), German Micro Census 1989, 1995, 1999, 2003, 2005, 2009, own calculations. 